\title{
Evolução estrutural dos Granitoides Arroio Divisa durante o movimento transcorrente da Zona de Cisalhamento Quitéria-Serra do Erval, Rio Grande do Sul

\author{
Structural evolution of the Arroio Divisa Granitoids during the transcurrent \\ movement of the Quitéria-Serra do Erval Shear Zone, Rio Grande do Sul
}

\author{
Evelin Roberta Schnorr ${ }^{1}$, Maria de Fátima Bitencourt ${ }^{1}$ (D) \\ ${ }^{1}$ Universidade Federal do Rio Grande do Sul - UFRGS, Instituto de Geociências, Programa de \\ Pós-Graduação em Geociências - PPGGEO, Avenida Bento Gonçalves, 9.500, Caixa Postal 15.001, \\ CEP 91501-970, Porto Alegre, RS, BR (evelinschnorr@yahoo.com.br; fatimab@ufrgs.br)
}

Recebido em 27 de outubro de 2017; aceito em 10 de julho de 2019

\begin{abstract}
Resumo
Os Granitoides Arroio Divisa (GAD) compreendem uma associação de rochas predominantemente granodioríticas, com termos dioríticos e tonalíticos em menor expressão. Apresentam textura heterogranular média a grossa e são sempre foliadas. Suas estruturas sugerem posicionamento em zona de cisalhamento dúctil correlacionada ao Cinturão de Cisalhamento Sul-brasileiro (CCSb), de idade neoproterozoica. Essas rochas registram cristalização com concomitante história deformacional sob condições de temperatura decrescente, evidenciada pela sobreposição concordante de estruturas magmáticas por estruturas de deformação de estado sólido em temperatura decrescente. A distribuição da deformação se dá de forma heterogênea ao longo da intrusão, gerando-se zonas de baixa e alta deformação inicialmente magmáticas e progredindo para o estado sólido. Nas porções internas do corpo intrusivo predominam estruturas de fluxo em que o alinhamento preferencial de forma é dominante, e a deformação interna dos marcadores é pouco desenvolvida. Em direção à borda norte da intrusão, a morfologia dessas estruturas progride por aumento na intensidade da deformação, com a geração de uma foliação fortemente milonítica paralela à trama magmática. Feições microestruturais de alta temperatura incluem o desenvolvimento de subgrãos em padrão tabuleiro de xadrez no quartzo, "e a geração de subgrãos grandes em cristais de K-feldspato e plagioclásio, que são compatíveis com temperaturas da fácies anfibolito superior e com a temperatura solidus de composições granítcas. As feições microestruturais de baixa temperatura consistem na recristalização dos cristais de quartzo por bulging, na neoformação de grãos finos ao redor dos cristais de feldspatos e no desenvolvimento de pertitas em chamas no K-feldspato, compatíveis com temperaturas da fácies xisto verde, bem abaixo da solidus. Portanto, as microestruturas de alta temperatura estariam associadas aos estágios iniciais de resfriamento e cristalização do magma, enquanto as de mais baixa temperatura seriam vinculadas aos estágios pós-cristalização, quando rocha plutônica e sua encaixante alcançam equilíbrio termal.
\end{abstract}

Palavras-chave: Magmatismo granítico; Sintectônico; Zona de cisalhamento transcorrente; Deformação sin-magmática.

\begin{abstract}
The Arroio Divisa Granitoids (ADG) comprise an association of predominantly granodioritic rocks, with minor dioritic and tonalitic varieties. They are medium- to coarse-grained rocks of heterogranular texture and foliated structure. Internal structures suggest their emplacement within a ductile transcurrent shear zone related to the Neoproterozoic Southern Brazilian Shear Belt. These rocks bear records of crystallization under stress deformation history and decreasing temperature conditions, which is outlined by the concordant overlapping of magmatic structures and those formed by solid-state deformation under high to low temperature. The distribution of structures within the intrusive body is heterogeneous, generating high- and low-strain zones formed in the magma and persisting throughout solid state. In the inner portions of the intrusion, there is predominance of flow structures where preferential shape orientation is dominant, and the internal deformation of markers is poorly developed. Toward the northern boundary of the intrusion, progressive increase of solid-state strain leads to the generation of a strong mylonitic foliation parallel to the magmatic fabric. High-temperature microstructural features include the development of the chessboard-pattern subgrains in quartz crystals and the generation of large subgrains in K-feldspar and plagioclase crystals, both compatible with upper amphibolite facies temperature conditions, and with the
\end{abstract}


solidus temperature of granitic compositions. Low-temperature microstructural features consist of bulging recrystallization in quartz, newly-formed fine grains around feldspar crystals and the development of flame perthites on K-feldspar, which is compatible with greenschist facies temperature conditions, far below the solidus. Therefore, high-temperature microstructures would be associated to the initial stages of magma cooling and crystallization, whereas the lower-temperature ones would point to the post-crystallization stage, when the plutonic rock and its host achieve thermal equilibrium.

Keywords: Granitic magmatism; Syntectonic; Transcurrent shear zone; Syn-magmatic deformation.

\section{INTRODUÇÃO}

$\mathrm{O}$ estudo das microestruturas encontradas em diferentes minerais, que se comportam reologicamente de maneiras distintas, é uma ferramenta precisa para estabelecer condições de temperatura em zonas de cisalhamento dúctil, uma vez que estas favorecem e condicionam o posicionamento de magmas. Assim, conforme Bitencourt (1996), é possível estabelecer um vínculo estreito entre a atividade magmática e a história geológica das zonas de cisalhamento, bem como determinar a posição da atividade magmática em relação à atividade tectônica, considerando que a atividade deformacional se prolonga após a cristalização completa do magma.

No Sul do Brasil, especialmente no Escudo Sul-riograndense (ESrg), as rochas graníticas representam registros importantes para a investigação da evolução da crosta, considerando-se que a maior parte dos terrenos pré-cambrianos no Estado é constituída, segundo Nardi e Bitencourt (2007), de granitoides e seus equivalentes metamórficos. O Ciclo Orogênico Brasiliano/Pan-africano, nessa região, é representado por ambientes de arco e colisionais associados com um expressivo volume de magmatismo granítico ao longo das zonas de cisalhamento que constituem o Cinturão de Cisalhamento Sul-brasileiro (CCSb) (Bitencourt e Nardi, 2000), entre elas, a Zona de Cisalhamento Quitéria Serra do Erval (ZCQSE) (Knijnik et al., 2013).

O presente trabalho apresenta e discute dados de campo, de geologia estrutural, petrográficos e especialmente microestruturais dos Granitoides Arroio Divisa (GAD), sintectônicos à ZCQSE. Levando-se em conta o registro de importantes informações acerca da história deformacional das rochas nas microestruturas (Passchier e Trouw, 2005) e as diferentes respostas minerais diante dos processos sofridos, objetiva-se determinar as condições deformacionais a que estavam submetidas as rochas estudadas quando se posicionaram, estabelecendo uma relação temporal entre o seu alojamento e a atividade da zona de cisalhamento.

Neste trabalho, o termo "deformação magmática" é empregado em referência à deformação sofrida por um magma, uma vez que se considere o material parcialmente solidificado, cuja temperatura permeia entre a da curva liquidus e a da curva solidus do sistema em questão. Sendo assim, considera-se que um material com $80 \%$ de cristais ainda é um magma e que apenas vai deixar de sê-lo ao atingir $100 \%$ de carga sólida. A capacidade dos magmas graníticos de concentrar deformação, resultando numa variedade de estruturas, tais como zonas de cisalhamento sin-magmáticas e diques sinplutônicos, é reconhecida por muitos autores (e.g., Walker, 1969; McCaffrey et al., 1999; Büttner, 1999; Mulchrone et al., 2005; entre muitos outros) e resulta do comportamento físico dos magmas como suspensões progressivamente mais densas. Para alguns autores (e.g., Paterson et al., 1989; Vernon, 2000), um conjunto de critérios pode ser aplicado na distinção, mas as estruturas geradas nos estágios mais tardios de cristalização tendem a convergir para aquelas geradas no estado sólido propriamente dito; no caso dos granitoides sintectônicos, a presença constante de um campo tensional durante a cristalização, e mesmo em condições subsolidus, torna, muitas vezes, pouco realista o traçado de tal linha divisória.

\section{CONTEXTO GEOLÓGICO REGIONAL}

A área de estudo situa-se no segmento leste do Escudo Sul-rio-grandense (ESrg) (Figura 1) e é composta especialmente por um grande volume de rochas granitoides dispostas em uma faixa de direção NE-SW. Essa massa de rochas graníticas faz parte do Cinturão Dom Feliciano (Fragoso Cesar, 1980), que se estende desde o Uruguai até Santa Catarina, e é compartimentado em três porções, que recebem as denominações de Batólito Pelotas no ESrg, Batólito Florianópolis, no Escudo Catarinense, e Batólito Aiguá, no escudo Uruguaio, constituindo a porção sul da Província Mantiqueira (Almeida et al., 1981).

Um expressivo volume de rochas que compõem o ESrg corresponde ao Neoproterozoico, cujo magmatismo, para Bitencourt e Nardi (2004), está relacionado a um período pós-colisional marcado por intensa atividade tectônica transcorrente. Nesse cenário, o CCSb (Bitencourt e Nardi, 2000), uma descontinuidade de escala translitosférica que compreende diversas zonas de cisalhamento anastomosadas, de mesma idade e cinemática transcorrente, é responsável pela gênese e evolução da maior parte dos granitoides encontrados na porção leste do escudo. Essa megaestrutura, que se estende de Santa Catarina ao sul do Uruguai, tem 
como principais segmentos, no Rio Grande do Sul, a Zona de Cisalhamento Transcorrente Dorsal de Canguçu (ZCTDC) (Fernandes et al., 1988), definida originalmente por Picada (1971) como Sistema de Falhas Dorsal de Canguçu, e a ZCQSE (Knijnik et al., 2013).

Os terrenos mais antigos na região de estudo (Figura 2) correspondem às rochas paleoproterozoicas, definidas por Gregory et al. (2011) como Complexo Arroio dos Ratos (CAR), constituído de tonalitos, granodioritos e dioritos metamorfisados que, de acordo com Gregory et al. (2015), foram deformados sob diferentes condições estruturais. Essas associações de rochas são delimitadas ao norte por uma zona de catáclase que oblitera seu contato original com as rochas granitoides sintectônicas à ZCTDC. Ao sul, são intrudidas pelos granitoides neoproterozoicos sintectônicos à ZCQSE, com os quais o contato se dá em uma zona de muito alta deformação.

A ZCQSE tem cerca de $30 \mathrm{~km}$ de extensão e $5 \mathrm{~km}$ de espessura. Tem direção ENE e é subvertical, com cinemática transcorrente sinistral. Essa estrutura condicionou o aporte, a ascensão e a evolução de grande parte dos granitoides sintectônicos registrados na porção leste do ESrg, intrusivos no CAR, em ordem cronológica: Granodiorito Cruzeiro do Sul (GCS) (Knijnik et al., 2010; Knijnik et al., 2012), GAD (Fontana et al., 2009; Fontana et al., 2012) e Granitoides Sanga do Areal (GSA) (Centeno, 2012).

Entre os granitoides pós-colisionais neoproterozoicos sintectônicos à ZCQSE, a unidade que representa o magmatismo mais precoce, o GCS (Knijnik et al., 2012), é um corpo de cerca de $4 \mathrm{~km}^{2}$, composto predominantemente de hornblenda-biotita granodioritos com idade de cristalização de $634 \pm 1.5 \mathrm{Ma}$ (U-Pb SHRIMP em zircão - Knijnik et al., 2010), de afinidade shoshonítica. É comum a ocorrência de xenólitos métricos a decamétricos do GCS nos GAD, evidenciando seu caráter precoce no magmatismo pós-colisional. As microestruturas descritas para o GCS, desenvolvidas sobre os feldspatos, indicam deformação

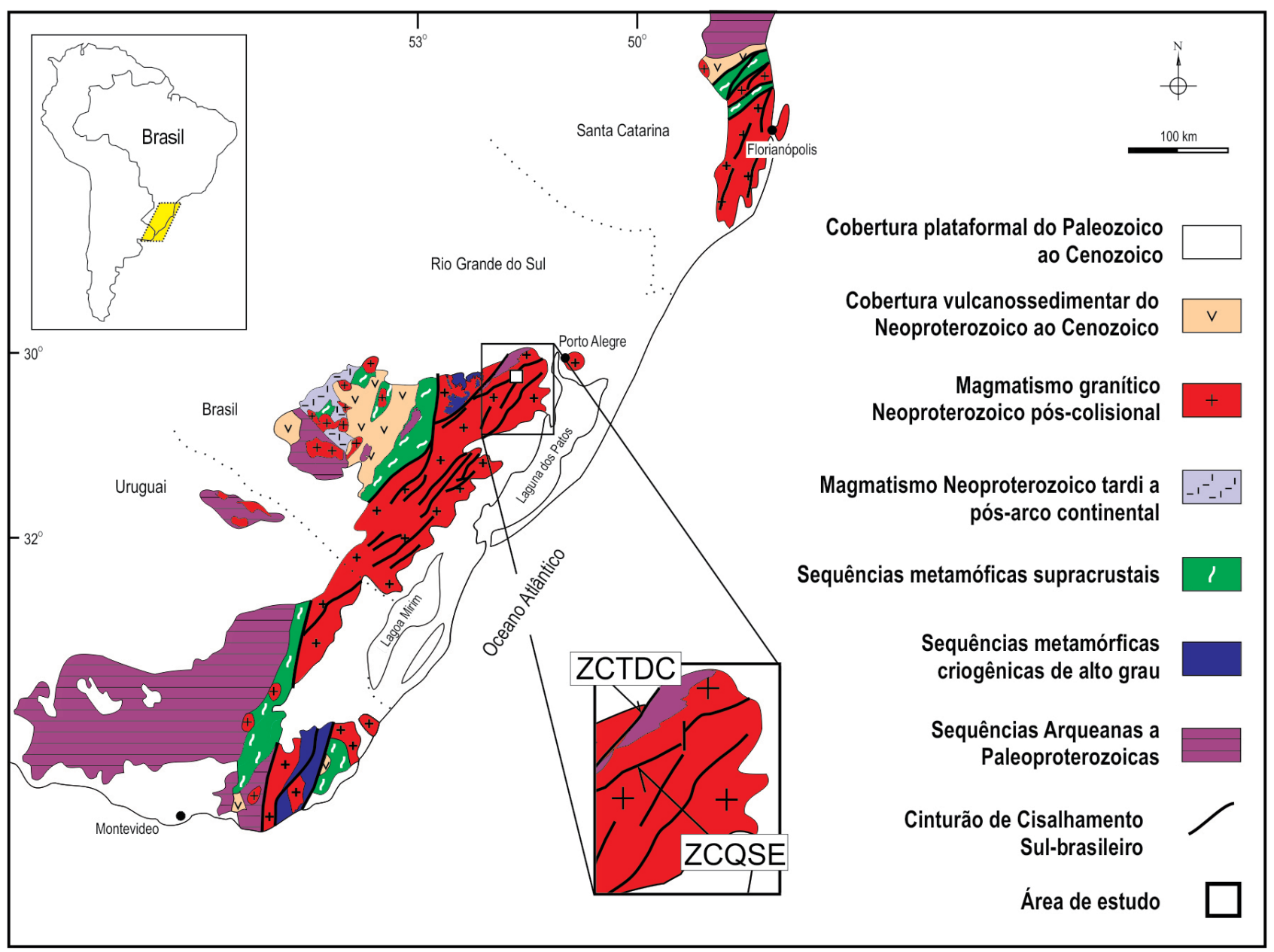

Fonte: extraído e modificado de Bitencourt e Nardi (2000).

Figura 1. Contexto geotectônico do segmento sul da Província Mantiqueira, com a demarcação da área de estudo. 
em condições de temperatura compatíveis com as da fácies anfibolito (Knijnik et al., 2012).

Associados temporal e espacialmente aos GAD, e caracterizando o magmatismo tardio do ambiente pós-colisional, estão os GSA (Centeno, 2012), que ocorrem como corpos alongados em uma área de aproximadamente $8 \mathrm{~km}^{2} \mathrm{ou}$, ainda, em corpos isolados, compreendendo biotita monzogranitos a granodioritos, porfiríticos, com foliação milonítica bem marcada pela orientação da biotita, dos megacristais lenticulares e do quartzo fitado. Ao comparar dados geoquímicos, mineralógicos e feições de campo entre essas duas associações, o mesmo autor aponta um caráter mais diferenciado para os GSA, sugerindo que estes representam um pulso magmático mais evoluído e mais jovem que os GAD, sendo ambos, no entanto, provenientes das mesmas fontes e produzidos pelos mesmos processos. Knijnik (2018) obteve para os GSA idade de cristalização de $620 \pm 5,6 \mathrm{Ma}$.

As idades magmáticas dos granitoides sintectônicos às duas zonas de cisalhamento na área de estudo, determinadas por Frantz et al. (2003), Koester et al. (2008) e Knijnik et al. (2012), limitam a sua idade mínima de atividade a um intervalo de 658 a $605 \mathrm{Ma}$. Considerando apenas a ZCQSE, as idades U-Pb em zircão obtidas para o GCS e os GSA permitem estimar um intervalo mínimo de movimentação em aproximadamente $8 \pm 6 \mathrm{Ma}$ (Knijnik et al., 2013). A fase posterior ao magmatismo sintectônico é caracterizada por reativações dessas zonas, evidenciadas pela ocorrência de quartzo-milonitos e filonitos, bem como zonas de catáclase sobrepostas.

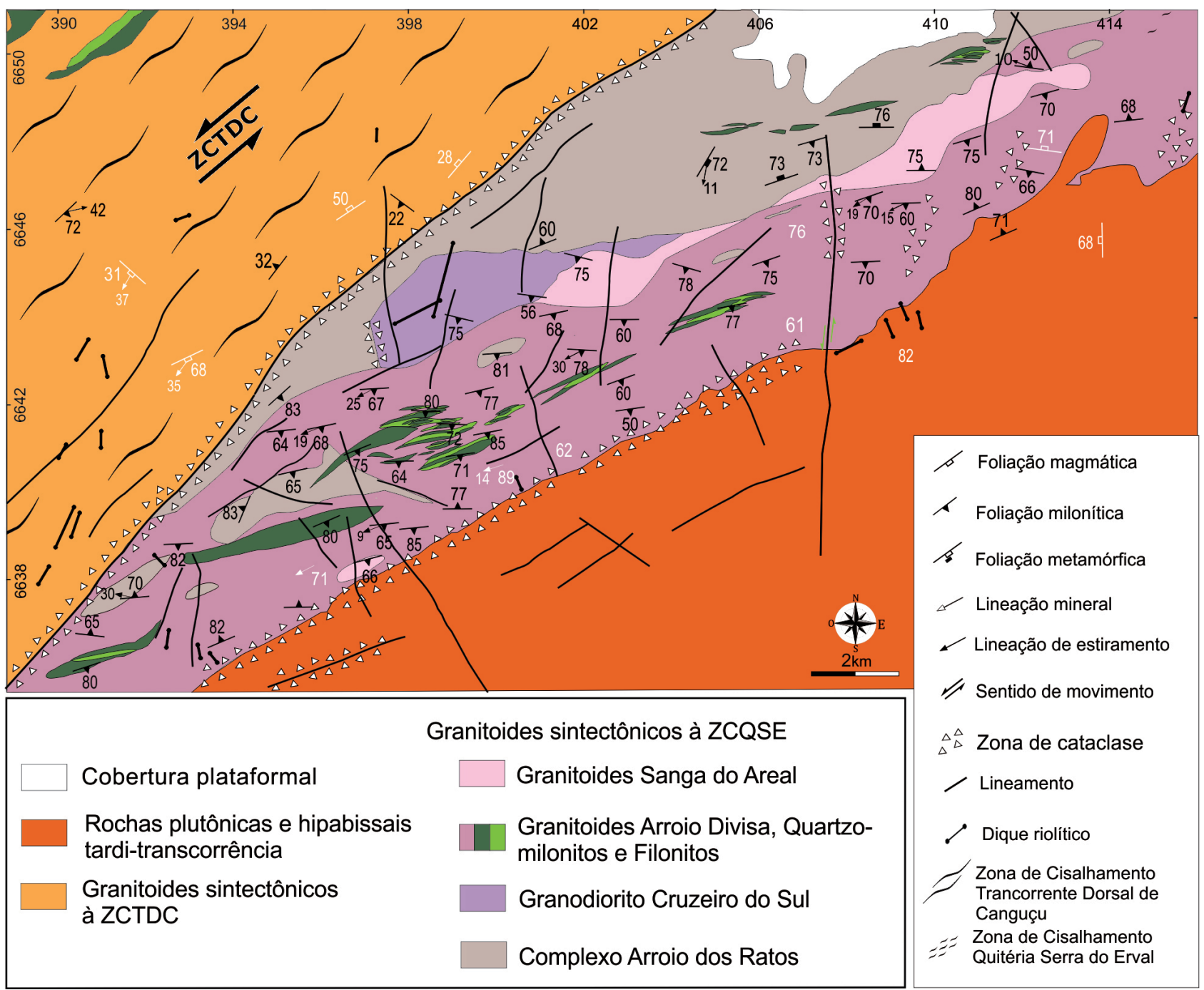

Fonte: extraído e modificado de Gregory et al. (2011).

Figura 2. Mapa geológico da região de estudo. 


\section{GEOLOGIA DOS GRANITOIDES ARROIO DIVISA}

\section{Características gerais}

Os GAD constituem uma associação de rochas predominantemente granodioríticas, com composições dioríticas e tonalíticas ocorrendo em menor expressão. A textura é heterogranular média a grossa e são sempre foliadas. De acordo com Fontana et al. (2012), essas rochas têm feições de mistura heterogênea com magmas básicos, além de produtos de hibridização localizada entre os termos extremos, gerados pela mistura efetiva durante a deformação, indicando a contemporaneidade entre os líquidos. As feições de mistura observadas em campo consistem em contatos ora interdigitados, ora gradacionais entre os termos máficos - representados por diques sinplutônicos e enclaves microgranulares máficos (EMM) — e as porções granodioríticas. Feições como assimilação mecânica de cristais de plagioclásio dos termos félsicos por EMM são indícios que também atestam a sincronicidade entre os magmas de diferentes composições.

Fontana et al. (2012) determinaram a afinidade toleítica médio a alto-K dos magmas máficos, e descrevem evidências sugestivas de caráter comagmático para a maior parte dos granodioritos e das rochas dioríticas dos GAD, apontando para a possibilidade de tratar-se de uma mesma associação petrológica, o que também é evidenciado por relações de campo, estruturais e estratigráficas. $\mathrm{O}$ modelo petrogenético proposto por Fontana et al. (2012) envolve processos de hibridização e mistura heterogênea de magmas, pressupondo a existência de um magma inicial de composição diorítica ou basáltica que teria se misturado com magmas graníticos. Conforme os mesmos autores, a gênese desses magmas está relacionada a uma mistura de fusões crustais e mantélicas, cujo provável contribuinte crustal poderia ser o embasamento paleoproterozoico representado pelo CAR.

\section{Caracterização das estruturas na escala da intrusão}

Os GAD formam um corpo alongado de direção ENE-WSW, com cerca de $30 \mathrm{~km}$ de extensão e $140 \mathrm{~km}^{2}$ de área aflorante (Figura 2). Ao norte, fazem contato intrusivo com as associações paleoproterozoicas do CAR e com as rochas neoproterozoicas GCS e GSA, onde se desenvolve uma zona de muito alta deformação. Ao sul, são intrudidos por rochas plutônicas e hipabissais de posicionamento tardio em relação à movimentação da ZCQSE e o contato é parcialmente obliterado por uma zona de catáclase, o que modifica a geometria original dos GAD e da zona de cisalhamento.

Esse corpo intrusivo apresenta ainda xenólitos e septos do embasamento, interpretados como roof pendants por Gregory et al. (2015), além de pequenas intrusões dos GSA. Quartzo-milonitos e filonitos ocorrem dispostos em faixas estreitas e alongadas ao longo dos GAD, com os quais suas estruturas são concordantes.

Nas porções internas do corpo predominam as estruturas resultantes de rotação corporal, com forte alinhamento preferencial de forma, mas com deformação interna pouco pronunciada e incompatível com o grau de alinhamento. Em direção à borda norte da intrusão, a morfologia dessas estruturas progride por aumento na intensidade da deformação interna, com a trama deformacional de estado sólido cada vez mais pronunciada e a geração de foliação milonítica tanto mais penetrativa quanto mais próximo o contato com a encaixante. Ainda assim, a deformação heterogênea do material parcialmente cristalizado resulta na concentração diferencial da deformação magmática progressivamente em direção à de estado sólido, obedecendo a concentração de strain inicial no magma. Formam-se, assim, zonas estreitas e alongadas de mais alta e mais baixa deformação alternadas, que constituem zonas de cisalhamento sin-magmáticas. O espaçamento entre elas é maior nas zonas internas do plúton e tende a diminuir em direção à borda norte do corpo, na qual a foliação milonítica é a trama principal. Pontualmente se observam estruturas primárias preservadas, mesmo nos domínios de muito alta deformação, atestando o seu caráter heterogêneo.

Com base na sua distribuição e morfologia, a foliação principal dos GAD é denominada primária $\left(\mathrm{S}_{0}\right)$ quando a trama resultante de rotação corporal é amplamente dominante. A transição da trama à medida que a cristalização avança, ainda sob tensão diferencial, resulta numa foliação em que a rotação corporal é ainda expressiva, mas é acompanhada de estiramento. É denominada foliação composta/magmático-deformacional $\left(\mathrm{S}_{0-\mathrm{m}}\right)$, característica de quantidades progressivamente menores de líquido magmático. A trama final, formada essencialmente no estado sólido ou diante de pequenas quantidades de líquido magmático, é denominada $\mathrm{S}_{\mathrm{m}}$. Essas estruturas planares são concordantes e têm direção preferencial ENE-WSW, com mergulho médio a alto, ora para S, ora para N. Tanto a lineação mineral (de fluxo) quanto a de estiramento têm baixo ângulo de caimento, predominantemente para W (Figura 3).

\section{Estruturas de mesoescala}

\section{Zonas de baixa deformação}

A heterogeneidade estrutural dos GAD se caracteriza principalmente pelo grau de desenvolvimento e morfologia das estruturas planares e lineares. Assim, nesse domínio uma foliação primária $\left(\mathrm{S}_{0}\right)$, marcada pela orientação preferencial de forma dos cristais de feldspatos e micas, com espaçamento milimétrico a centimétrico entre os planos, é acompanhada pela geração de estruturas de deformação de estado sólido de baixa intensidade. As condições ainda 
magmáticas de $\mathrm{S}_{0}$ são progressivamente acrescidas de uma componente de strain, caracterizada pelo estiramento de quartzo e feldspatos e pelo desenvolvimento de caudas assimétricas de recristalização em porfiroclastos de feldspatos, resultando na formação de uma trama composta $\left(\mathrm{S}_{0-\mathrm{m}}\right)$. Retratando a heterogeneidade, a partição da deformação ao longo da intrusão e o caráter transicional dos processos deformacionais, ocorrem nessa porção do corpo granítico faixas miloníticas, com o desenvolvimento de foliação $\mathrm{C}$, ainda que de forma pouco expressiva.

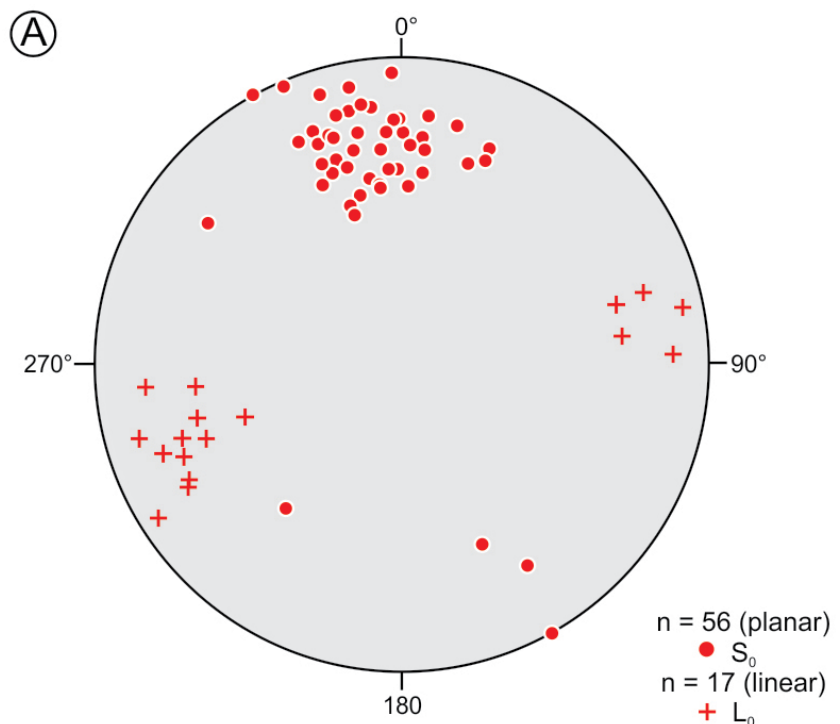

A morfologia da foliação dos GAD varia quando em contato com xenólitos do embasamento, sendo notavelmente mais desenvolvida quando comparada às ocorrências mais distantes dos xenólitos. Estes, por sua vez, são muito comuns e são geralmente concordantes com a foliação ou rotacionados progressivamente para sua orientação. Variam de centimétricos a métricos, e alguns eventualmente registram uma deformação por cisalhamento destral (Figura 4A), mais antigo, que contrasta com a deformação sinistral marcada por injeções de líquidos félsicos dos GAD

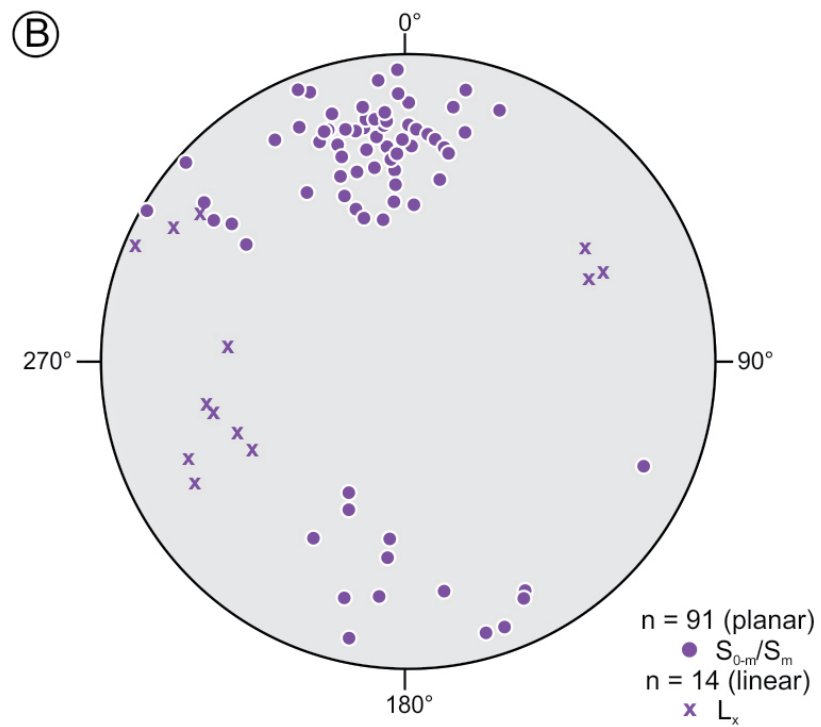

Figura 3. Representação estereográfica (hemisfério inferior) das estruturas planares e lineares dos GAD. (A) Foliação primária e lineação mineral. (B) Foliação milonítica e lineação de estiramento.
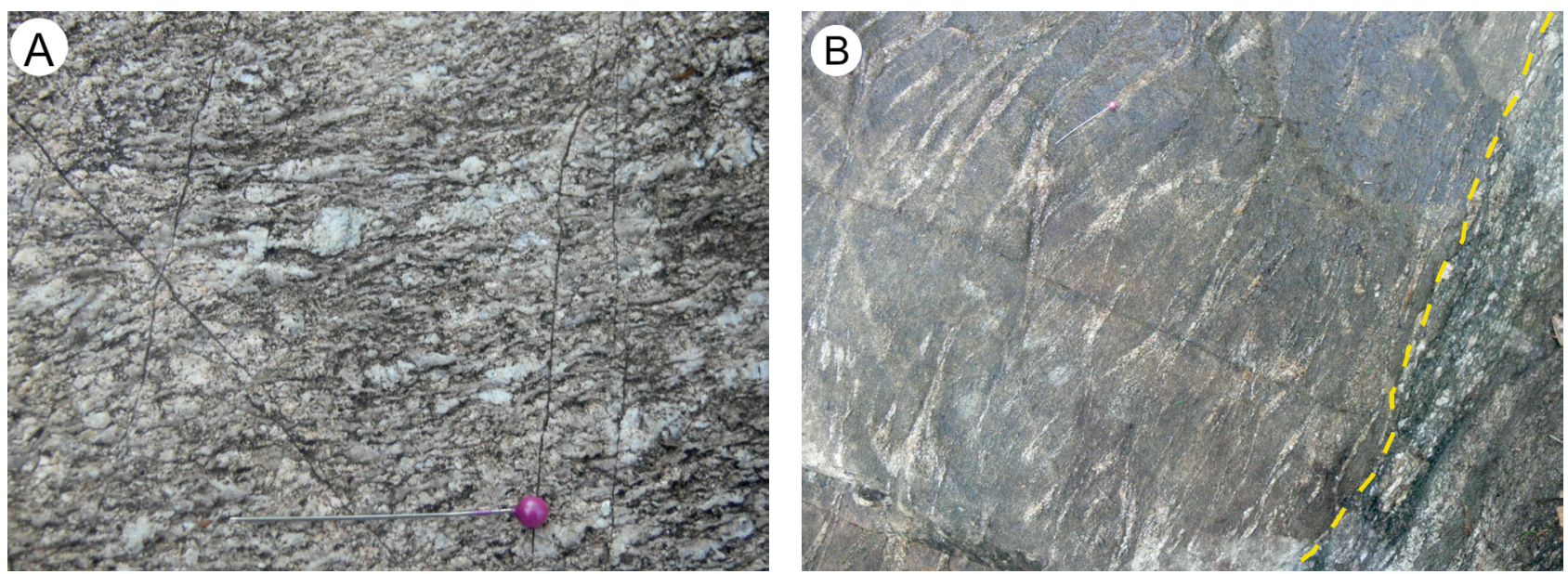

Figura 4. Feições de meso escala em zona de mais baixa deformação. (A) Foliação milonítica das rochas encaixantes dos GAD, com indicadores cinemáticos destrais. (B) Contato entre os GAD (direita) e os metatonalitos do seu embasamento (esquerda), nos quais se observam estreitas injeções leucograníticas provenientes dos GAD, com geometria compatível com o cisalhamento esquerdo ativo durante seu posicionamento, e aspecto milonítico dos GAD realçado no contato. (Comprimento do alfinete $=3,5 \mathrm{~cm}$ ). 
(Figura 4B) sincrônica ao seu posicionamento. Essas injeções frequentemente estão dobradas, estiradas e boudinadas.

Localmente, faixas de espessura métrica paralelas à foliação se desenvolvem nessas rochas (Figura 5A), com estrutura planar estreitamente espaçada, granulação mais fina que os termos típicos, contendo injeções félsicas e cristais de plagioclásio de tamanhos que variam de $0,3 \mathrm{~mm}$ até cerca de $4 \mathrm{~cm}$ (Figura 5B). $\mathrm{O}$ grau de desenvolvimento da foliação, que é mais intenso nessas faixas, não é compatível com um aumento da deformação, que é a mesma das porções adjacentes. A granulação mais fina nessas faixas pode ser atribuída ao crescimento inibido pela velocidade de fluxo, como o que seria esperado em um corredor de fluxo.

As relações com os termos híbridos e mistura heterogênea com magmas máficos são bem retratadas na ocorrência frequente de EMM de dimensões centimétricas a decamétricas. Em geral, são alongados conforme a foliação e comumente contêm cristais de plagioclásio de $0,2 \mathrm{~mm}$ até cerca de $1 \mathrm{~cm}$, mecanicamente assimilados a partir da rocha principal, o que evidencia a contemporaneidade entre os magmas (Figura 5C).
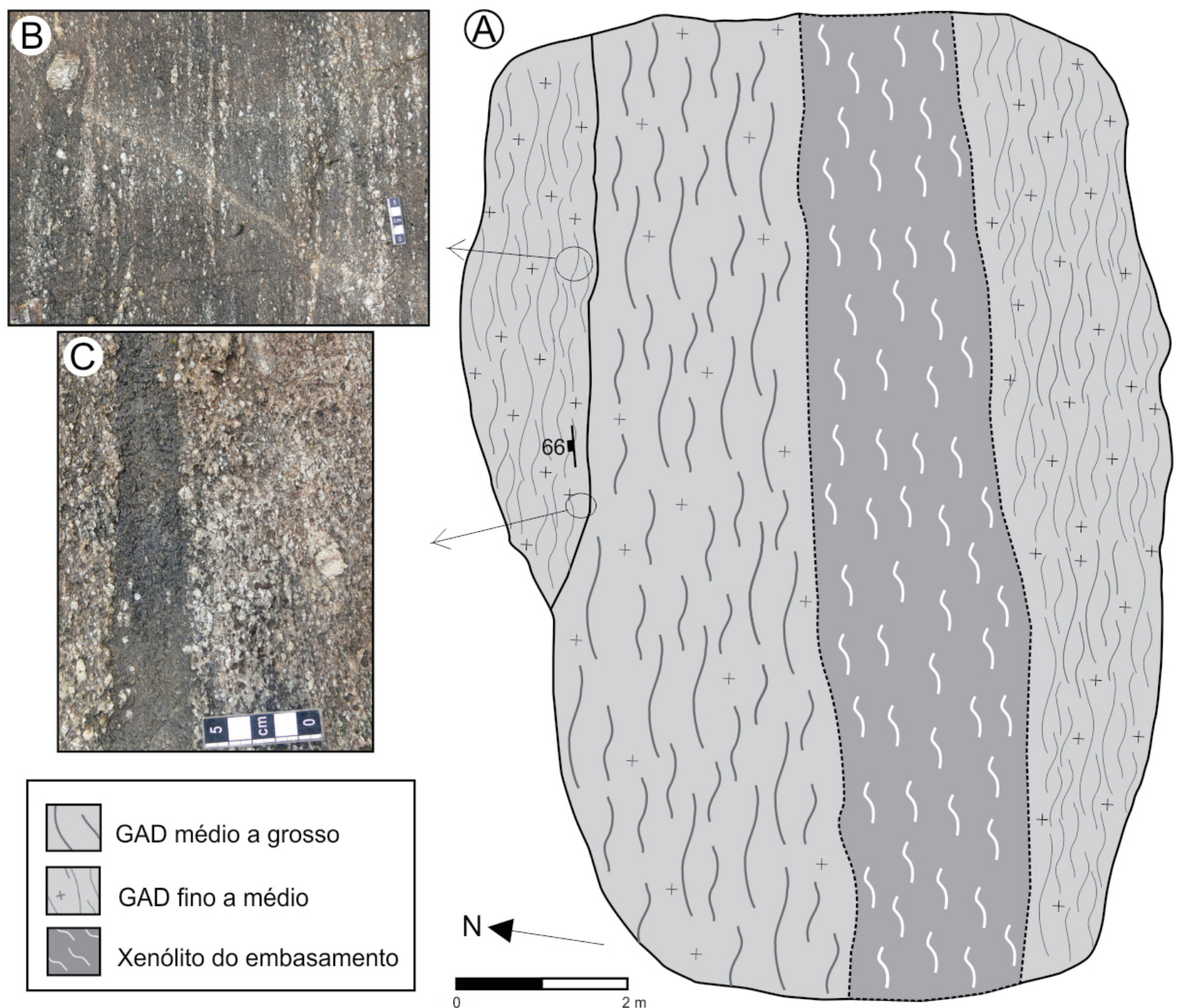

GAD médio a grosso

GAD fino a médio

Xenólito do embasamento

0

Figura 5. (A) Croqui esquemático dos GAD em zona de mais baixa deformação, com a ocorrência de corredores de fluxo, e xenólitos do embasamento concordantes com a foliação do granitoide. (B) Feição correspondente ao corredor de fluxo, com foliação finamente espaçada, granulação fina, contendo injeções félsicas alongadas na foliação e cristas de plagioclásio com até $4 \mathrm{~cm}$. (C) Enclave microgranular máfico com cristais de plagioclásio mecanicamente assimilados da porção félsica adjacente. 


\section{Zonas de alta deformação}

À medida que a progressão da foliação milonítica $\left(\mathrm{S}_{\mathrm{m}}\right)$ avança sobre a foliação magmática $\left(\mathrm{S}_{0}\right)$, obliterando as relações primárias, configura-se uma zona intensamente deformada, com a deformação de estado sólido de alta temperatura progredindo para a de média e baixa temperatura. A foliação milonítica se desenvolve com graus de intensidade variável, ora com granulação mais grossa e planos espaçados centimetricamente (Figura 6A), ora com forte estiramento dos minerais, intensa cominuição dos cristais e planos muito finamente espaçados (Figura 6B). Estruturas do tipo S-C são comuns nessas porções (Figura $6 \mathrm{C}$ ), com a foliação C espaçada milimetricamente e em ângulo muito baixo com a S, o que é compatível com o alto grau de deformação dessa porção. A foliação $\mathrm{S}$ é marcada pelo alinhamento dos cristais de feldspato bem formados, de $0,5 \mathrm{~mm}$ a aproximadamente $3 \mathrm{~cm}$, enquanto as caudas assimétricas dos porfiroclastos de feldspato deformados e a orientação dos agregados centimétricos de biotita evidenciam a foliação $\mathrm{C}$. Em porções nas quais a deformação é muito intensa, planos C' se desenvolvem como novas frentes de acomodação da deformação, que não é mais comportada pela foliação $C$. A rotação dos planos $\mathrm{S}$ para os planos $\mathrm{C}$, bem como dos planos $\mathrm{C}$ para C', indicam movimento lateral esquerdo.

A estrutura linear $\left(\mathrm{L}_{\mathrm{x}}\right)$ é marcada pelo forte estiramento, principalmente de quartzo e feldspatos (Figuras 6D e 6E), e tem baixo ângulo de caimento, ora para $\mathrm{W}$, ora para $\mathrm{E}$.

Lateralmente, e de forma pontual, ocorrem zonas centimétricas de muito alto strain (Figura 6F), com intensa cominuição dos cristais de quartzo e foliação estreitamente espaçada, contrapondo-se às zonas de relativamente menor strain, de granulação grossa e foliação mais espaçada. Nessas faixas em que a deformação se concentra, a quantidade de matriz recristalizada aumenta consideravelmente às expensas da redução de tamanho dos porfiroclastos de feldspatos.

Diques sinplutônicos máficos de espessura métrica (Figuras 7A e 8) são subconcordantes com a estrutura planar dos GAD, com contatos geralmente nítidos e, em alguns casos, interdigitados (Figura 8A) ou gradacionais (Figura 8B). Frequentemente contêm injeções félsicas de 2 a $3 \mathrm{~mm}$ até cerca de $5 \mathrm{~cm}$ de espessura e veios leucograníticos dobrados por cisalhamento, com flancos boudinados (Figura 8C), indicando uma componente extensional progressiva. Xenólitos tabulares do embasamento e do GCS (Figura 7B) são comuns, geralmente concordantes com a estrutura dos GAD e, com frequência, parcialmente assimilados.

\section{Indicadores cinemáticos}

Em mesoescala, diversas feições podem ser utilizadas como indicadores cinemáticos do movimento transcorrente sinistral da ZCQSE. Em zona de baixa deformação, a relação espacial entre a foliação primária $\left(\mathrm{S}_{0}\right)$ e a foliação $\mathrm{C}$ magmática aponta o movimento anti-horário para a ZCQSE. Do mesmo modo, a ocorrência de injeções de líquidos félsicos dos GAD nos xenólitos de sua encaixante e a frequente rotação dos xenólitos adentrando a foliação dos granitoides apontam o mesmo sentido de movimento. Na zona de alta deformação, o movimento sinistral da ZCQSE é evidenciado pela relação espacial entre as foliações S-C-C', o que também é confirmado pelo desenvolvimento de caudas de recristalização em porfiroclastos de feldspatos deformados.

\section{Petrografia e microestruturas}

\section{Zonas de baixa deformação}

Os GAD constituem predominantemente monzogranitos e granodioritos foliados, de textura heterogranular média a grossa, contendo zircão e apatita como minerais acessórios. Nesse domínio, assim como nos domínios de mais alta deformação, são evidenciados processos que ocorrem em uma sequência contínua de cristalização magmática, acompanhada de deformação de estado magmático e subsequente deformação de estado sólido. A foliação é marcada pela orientação dimensional dos cristais de feldspato e lamelas de biotita, entremeada por recristalização dinâmica dos cristais de quartzo e feldspatos.

O plagioclásio tem composição $\mathrm{An}_{37-45}$, com tamanhos de 0,6 a $4 \mathrm{~mm}$. Inclusões de biotita e apatita são raras. Micas brancas ocorrem frequentemente como mineral de alteração. Os cristais de plagioclásio são geralmente prismáticos, têm extinção ondulante e apresentam maclas de crescimento segundo as leis da Albita-Carlsbad e Albita longitudinais (Figura 9A), em geral subparalelas ao plano da foliação principal. Maclas tectônicas ocorrem pontualmente (Figura 9B), assim como kink bands (Figura 9C). Subgrãos não são comuns, mas ocorrem de forma localizada (Figura 9D).

O K-feldspato varia de 0,5 a $5 \mathrm{~mm}$, em geral pertítico, com predomínio de pertitas do tipo fita e lamelas. Alguns megacristais contêm inclusões de biotita, quartzo e plagioclásio (Figura 10A). Esses cristais respondem pela deformação exibindo extinção ondulante setorizada, acompanhada, muitas vezes, de subgrãos e recristalização localizada. Feições de exolução na forma de coroas trocadas podem ocorrer nos cristais de $\mathrm{Kfs}$ e, embora pouco comuns, são bem preservadas e representam feições tardi-magmáticas. A presença de agregados mirmequíticos é localizada (Figura 10B), ocorrendo nas bordas dos cristais e nos contatos com cristais de plagioclásio. Microfraturas extensionais são comuns nos cristais de Kfs, muitas vezes seladas por grãos de morfologia compatível com a dos grãos encontrados na matriz recristalizada. Eventualmente, é possível verificar a continuidade física entre o preenchimento das fraturas e a 

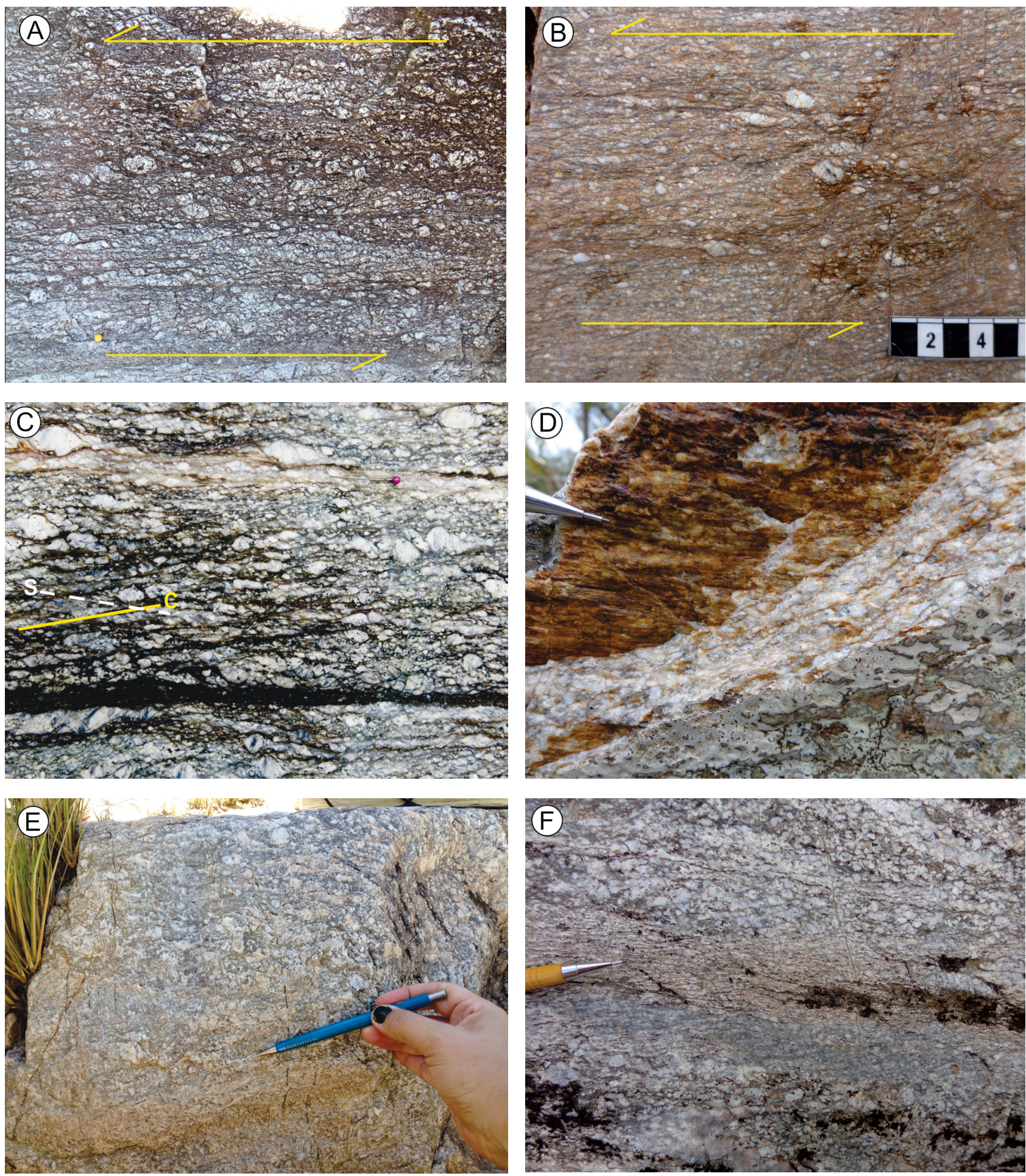

Figura 6. Feições de mesoescala em zonas de mais alta deformação. (A) e (B) Aspectos da foliação milonítica, com graus de intensidade variável. Em $(A)$, a rocha com granulação mais grossa e espaçamento centimétrico entre os planos. Em (B), os cristais mais cominuídos e a foliação milimétricamente espaçada. (C) Desenvolvimento do par SC, indicando o movimento em sentido anti-horário. (D) e (E) Lineação de estiramento com baixo ângulo de caimento no plano da foliação milonítica. (F) Intercalação de zonas de mais alta e mais baixa deformação em escala de afloramento, atestando a heterogeneidade da distribuição da deformação com a geração de microzonas de muito alto strain. 

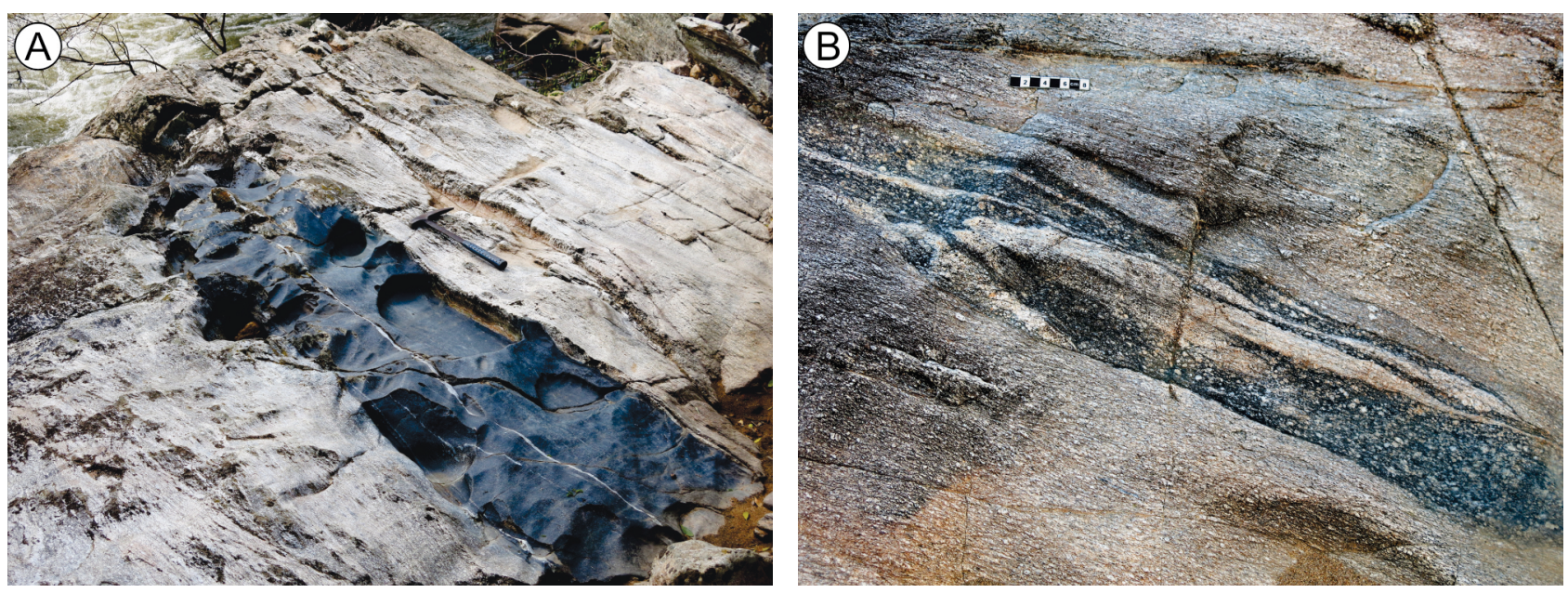

Figura 7. (A) Dique sinplutônico máfico subconcordante com a estrutura planar dos GAD. (B) Xenólito tabular do Granodiorito Cruzeiro do Sul concordante com a estrutura planar dos GAD.

(A)

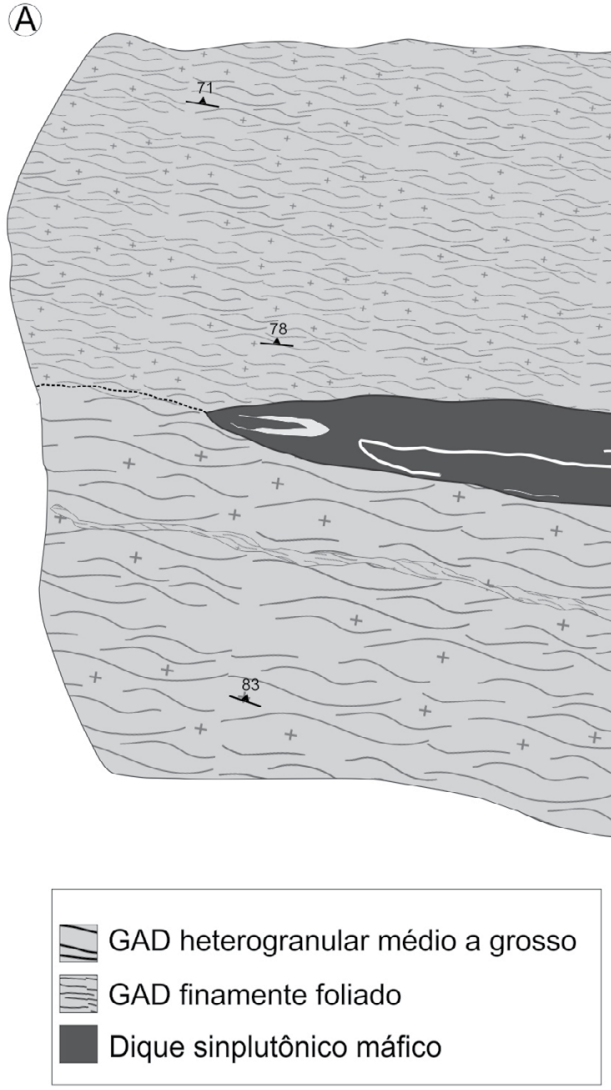

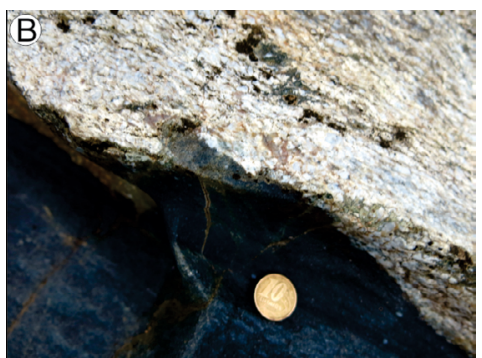
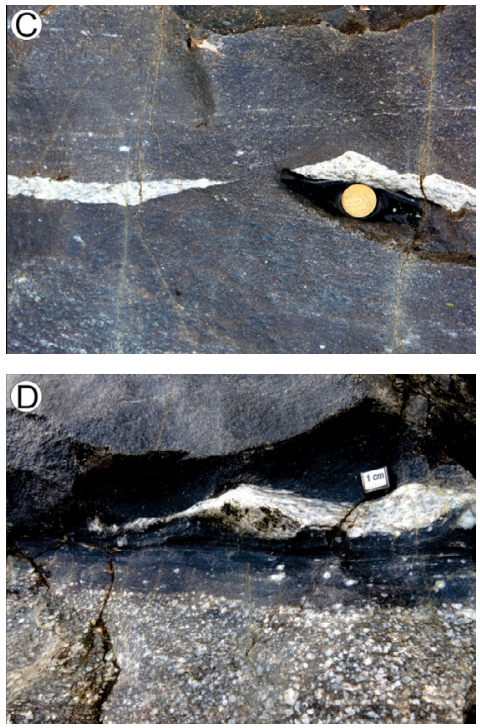

Figura 8. (A) Croqui esquemático da relação concordante entre dique sinplutônico máfico e GAD, demonstrando a variação textural e deformacional nos granitoides. (B) Contato sul-interdigitado entre dique e granitoide. (C) Veio leucogranítico boudinado. (D) Contato entre dique e GAD na porção norte do afloramento, evidenciando a hibridização entre os dois magmas. 
matriz e, dessa forma, atribuir o comportamento rúptil dos feldspatos à fase magmática.

Alguns cristais de quartzo preservam ainda feições ígneas; todavia, deformação de estado sólido, tanto de alta quanto de baixa temperatura, é verificada pela presença de estruturas como subgrãos em padrão tabuleiro de xadrez (Figura 10C), recristalização por migração de limite de grão, extinção ondulante e recristalização por bulging (Figura 10D). É comum a ocorrência de agregados policristalinos alongados e lenticulares de quartzo circundando os feldspatos.

A biotita primária tem coloração avermelhada para $\mathrm{n}_{\mathrm{g}} \mathrm{e}$ ocorre como lamelas inclusas nos feldspatos ou como agregados de lamelas intersticiais, estes geralmente orientados na foliação. Nos corredores de fluxo, a deformação registrada nos GAD tem a mesma intensidade das porções adjacentes, com a foliação marcada pelo alinhamento dimensional dos cristais de feldspato, lamelas de biotita e cristais de quartzo estirados, bem como, em menor expressão, por cristais maiores de feldspato alongados. Os cristais de K-feldspato são, em geral, ígneos, com extinção ondulante. O quartzo ocorre pontualmente ígneo, mas predominantemente recristalizado por bulging. São comuns nesses cristais o padrão de subgrão em tabuleiro de xadrez e o desenvolvimento de extinção ondulante. No plagioclásio, em geral bem preservado, o desenvolvimento de maclas tectônicas e da Albita e AlbitaCarlsbad é frequente. Subgrãos muito finos são observados, de forma restrita, nas bordas desses cristais. Microfraturas são comuns e kink bands ocorrem localmente.

\section{Zonas de alta deformação}

As tramas registradas nesse domínio refletem a heterogeneidade da distribuição da deformação sofrida pelos GAD, que pode ser observada mesmo em escala de
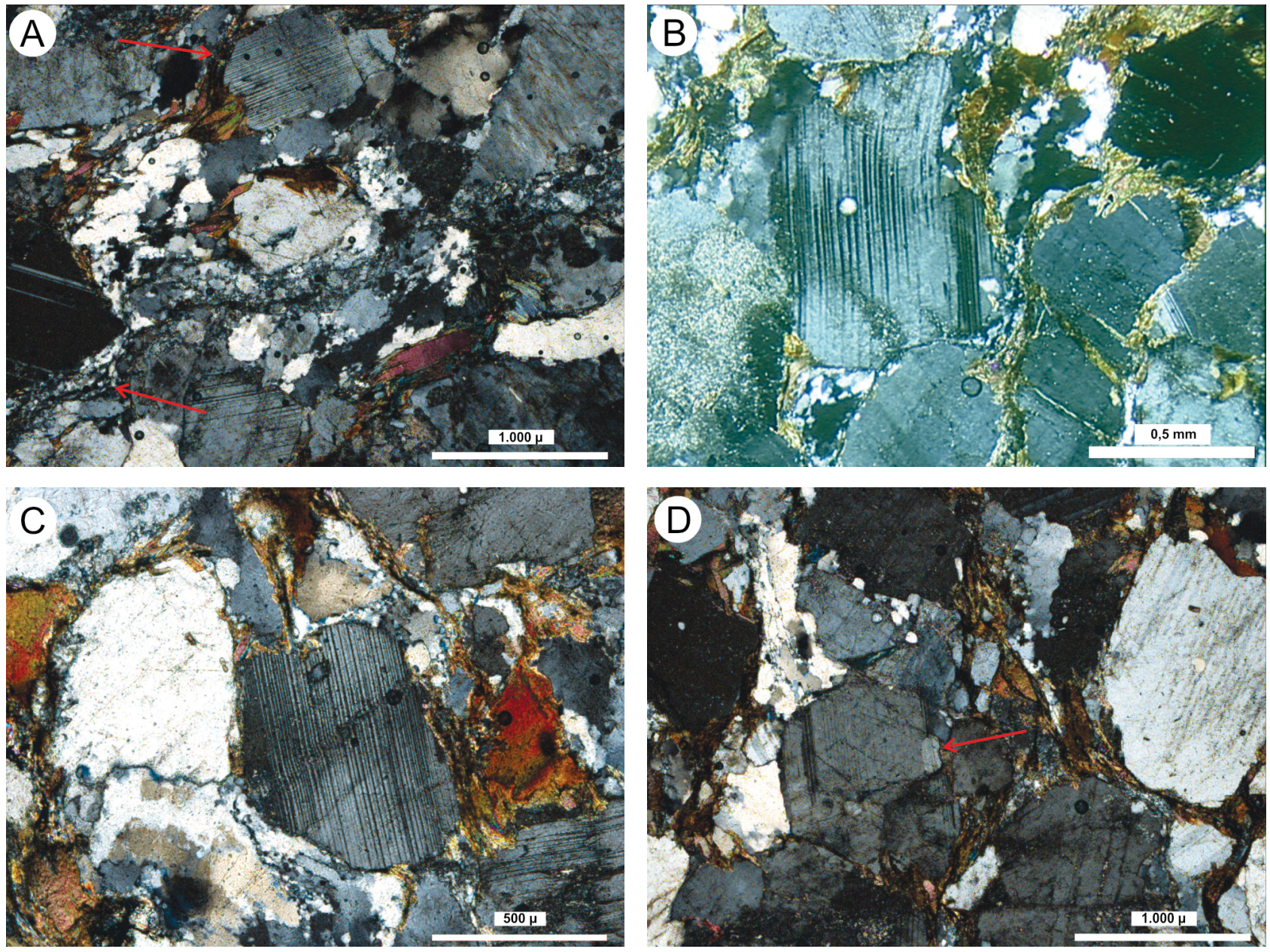

Figura 9. (A) Cristais de plagioclásio subédricos, com maclas de crescimento, e quartzo recristalizado por bulging. (B) Cristal de plagioclásio com macla tectônica encurvada. (C) Kink band afetando maclas de crescimento em plagioclásio.

(D) Cristal de plagioclásio com subgrão formado por rotação. 
lâmina (Figuras 11 e 12). Nesse cenário, os GAD ocorrem com suas variadas feições deformacionais, progredindo, muitas vezes, de rochas protomiloníticas a miloníticas, em processos que envolvem a recristalização dinâmica em quartzo e feldspatos compatíveis com temperaturas da fácies xistos verdes médio a superior.
A principal estrutura planar é a foliação milonítica, aliada ao desenvolvimento de uma foliação cisalhante, $\mathrm{C}$, constituindo um par S-C, no qual a S é marcada pela orientação das lamelas de biotita e porfiroclastos de feldspatos. A foliação C é evidenciada pela orientação de micas brancas e pelas caudas assimétricas de recristalização dos
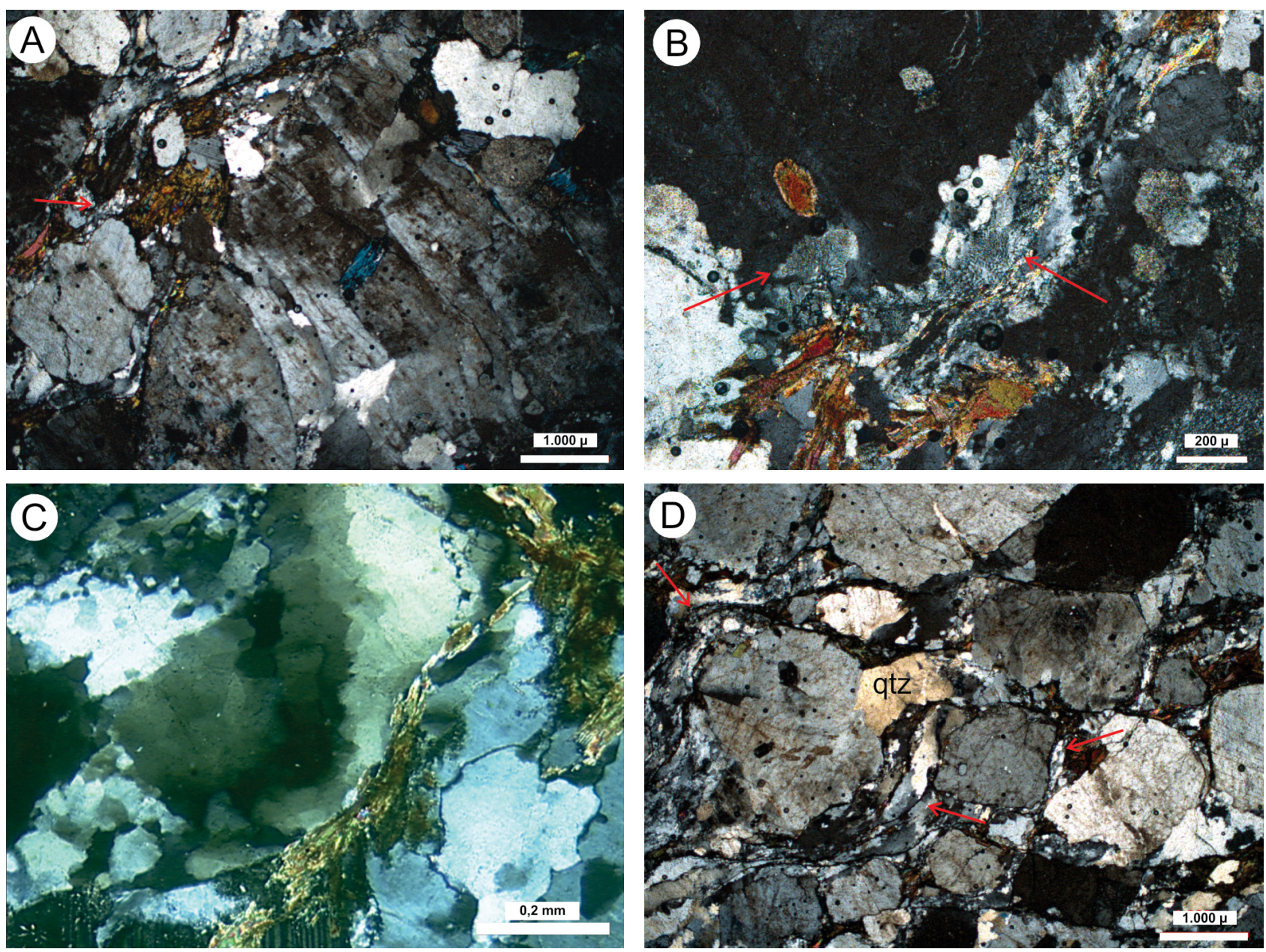

Figura 10. (A) Megacristal de K-feldspato fraturado, com extinção ondulante setorizada e inclusões de biotita cloritizada, plagioclásio e quartzo. Cristais de quartzo recristalizados na matriz contornam os porfiroclastos de feldspatos. (B) Mirmequitos na borda dos cristais de K-feldspato. (C) Subgrãos ortogonais configurando o padrão tabuleiro de xadrez em cristal de quarzto. (D) Cristais de quartzo e plagioclásio contornados por quartzo recristalizado na matriz.
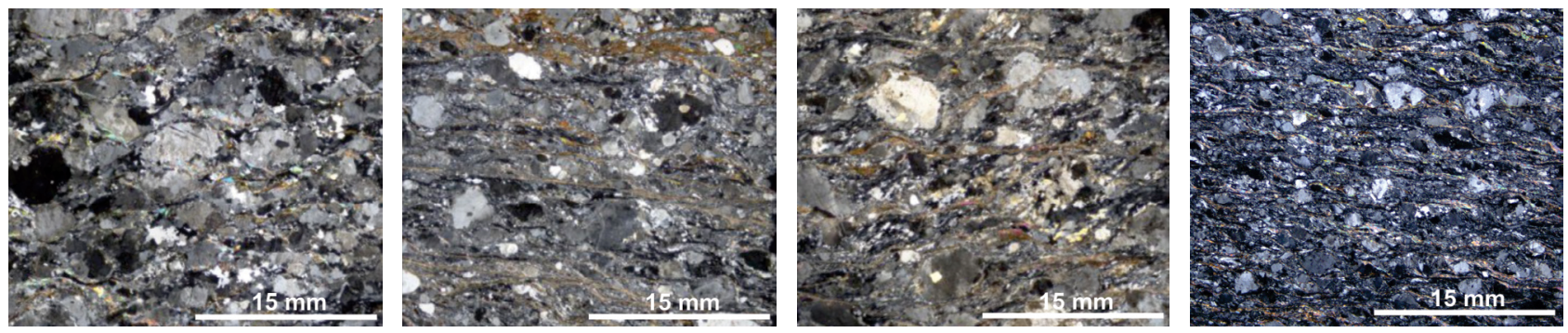

Figura 11. Feições microscópicas dos GAD nos domínios de deformação de estado sólido, demonstrando as variações no grau de recristalização dinâmica dessas rochas. 
porfiroclastos, que assinalam o sentido de movimento sinistral da ZCQSE.

Os cristais de plagioclásio são anédricos a subédricos, com teor de $\mathrm{An}_{27-33}$ e tamanhos de 0,01 a 1,8 mm, com extinção ondulante, por vezes setorizada. A alteração nesses cristais é muito expressiva e a maior parte contém maclas tectônicas (Figura 13A) e maclas de crescimento segundo a lei da Albita e Albita-Carlsbad. Subgrãos ocorrem localmente, com tamanhos de aproximadamente $0,3 \mathrm{~mm}$, e recristalização também é observada. A presença de subgrãos grandes (Figura 13B), de limites geralmente curvos, embora de forma local, é compatível com temperaturas elevadas de deformação. A proximidade entre a orientação do grão e a da região recuperada sugere um processo de rotação progressiva da rede cristalina a fim de acomodar os movimentos das deslocações, o que, para Tullis e Yund (1991), exige temperaturas compatíveis com as da fácies anfibolito superior nos feldspatos. Esses cristais fazem contatos irregulares com outros cristais ou contatos diretos com lentes de quartzo e biotita na foliação. De forma subordinada, são margeados por finas lentes incompletas de grãos feldspáticos e lamelas de micas muito finas.

Os K-feldspatos formam cristais anédricos e geralmente maiores que os de plagioclásio, com tamanhos de 0,06 a $1,5 \mathrm{~mm}$. Possuem pertitas com morfologia variável, predominando pertitas em fitas e, pontualmente, pertitas em chamas (Figura 13C). Estas últimas se formam preferencialmente das bordas para o centro dos cristais, em que a tensão e a instabilidade do cristal tendem a ser maiores. Inclusões, de plagioclásio e biotita, são pouco abundantes, ambos geralmente alterados para micas brancas e clorita, respectivamente. Os cristais de Kfs são, por vezes, circundados de forma incompleta por cristais menores de plagioclásio e, principalmente, por quartzo recristalizado, ou fazem contato direto com as lamelas de mica na foliação e irregular com outros feldspatos. A presença de agregados mirmequíticos (Figura 13D) é comum nas bordas dos Kfs e no seu contato com cristais menores de plagioclásio. Assim como o plagioclásio, esses cristais têm extinção ondulante setorizada (Figura 13E)
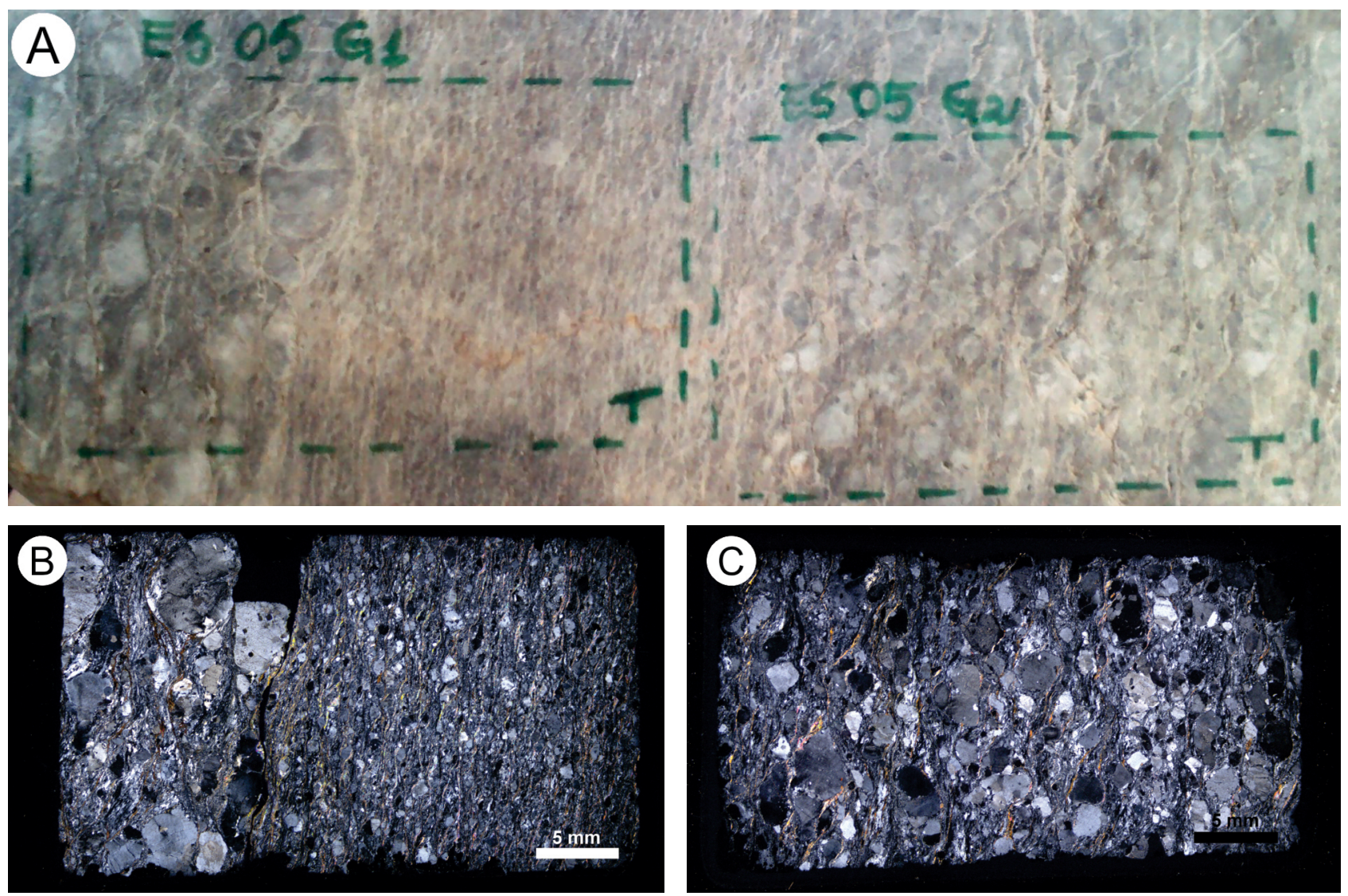

Figura 12. (A) Amostra macroscópica evidenciando as microzonas de espessura centimétrica de altíssima deformação. Visão geral de duas lâminas confeccionadas a partir de uma mesma amostra, demonstrando a variação lateral que configura a heterogeneidade da deformação em microescala. (B) Intensa milonitização, com cristais muito cominuídos e foliação finamente espaçada, contrapondo-se à (C) porção de granulação mais grossa e foliação mais espaçada. 
e frequentemente constituem porfiroclastos com caudas recristalizadas que atestam o caráter sinistral do movimento (Figura 13F). Subgrãos são frequentes, com tamanhos que variam entre 0,3 e $0,9 \mathrm{~mm}$, e grãos recristalizados com aproximadamente $0,2 \mathrm{~mm}$ concentram-se nas bordas dos cristais (Figura 14A), gerados em resposta à rotação de subgrão, o que é evidenciado pelo seu baixo ângulo de desorientação. Embora concentrada nas bordas, a recristalização, nos termos mais deformados, avança para as porções internas dos cristais. A maior parte dos cristais
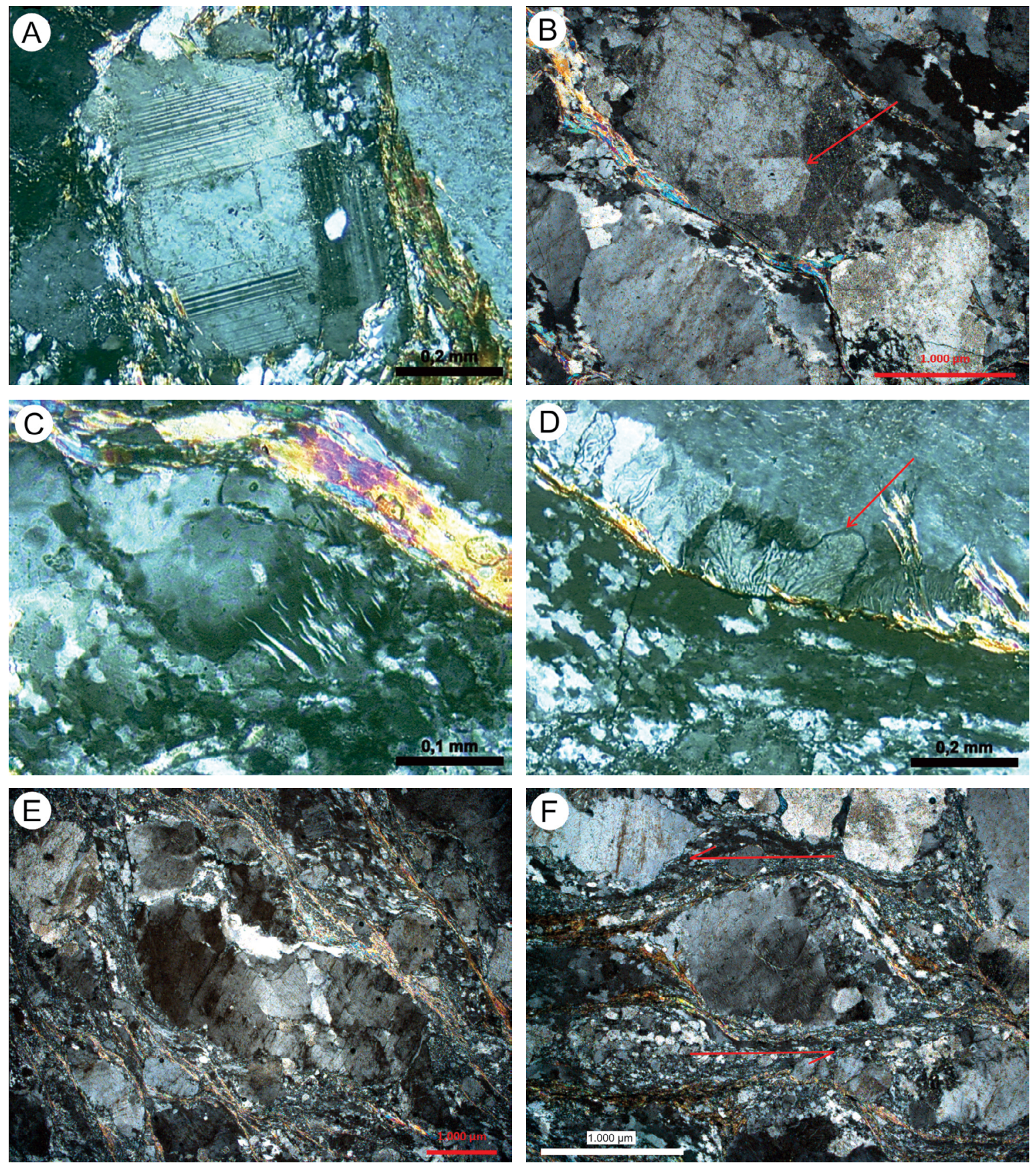

Figura 13. (A) Maclas tectônicas em cristal de plagioclásio. (B) Subgrão grande em cristal de plagioclásio com baixo ângulo de desorientação entre grão e subgrão. (C) Pertita em chamas na borda de cristal de K-feldspato. (D) Mirmequitização na borda de cristal de K-feldspato. (E) Porfiroclasto de K-feldspato com extinção ondulante setorizada e subgrãos grandes no centro do cristal (F) Porfiroclasto de K-feldspato com cauda de recristalização e agregado de quartzo lenticular. 
de Kfs é intensamente afetada por microfraturas nas quais, com frequência, observa-se a continuidade física entre o material que as preenche e a matriz, atestando que estas feições são formadas em alta temperatura, quando ainda havia líquido para selá-las (Figura 14B).
O grau de recristalização do quartzo é variável, com a ocorrência de recristalização por migração de limite de grãos (Figuras 14C e 14D), rotação de subgrão e bulging (Figura 14E). Lentes de agregados policristalinos orientadas na foliação circundam os megacristais de feldspatos e são
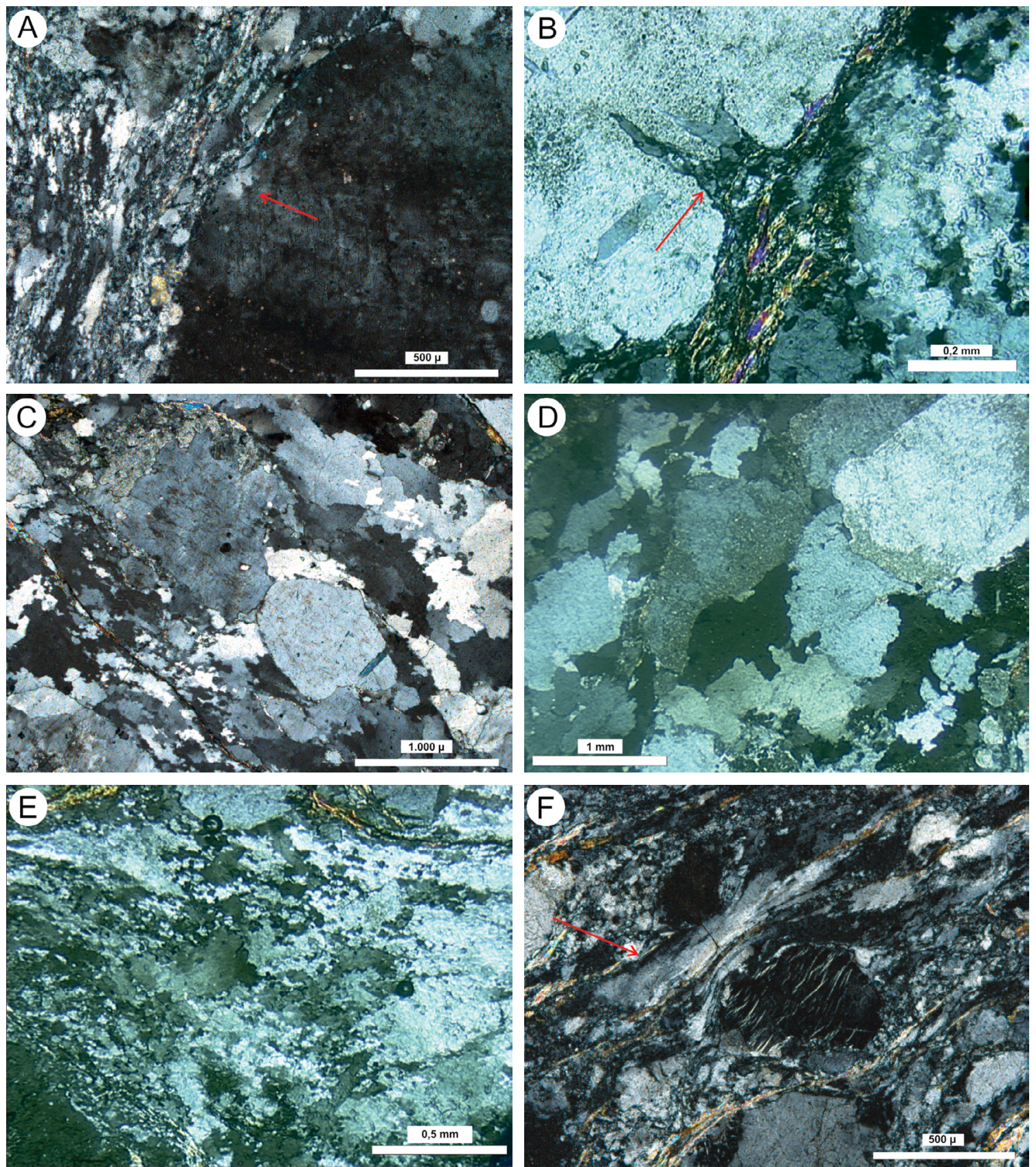

Figura 14. (A) Subgrãos na borda de K-feldspato. (B) Microfratura em feldspato selada por material recristalizado em continuidade óptica com a matriz. (C) Aspecto textural dos GAD, demonstrando intensa recristalização e redução da granulação no quartzo. (D) Intensa recristaliação por migração de limite de grão em quartzo. (E) Intensa recristalização de quartzo por bulging. (F) Porfiroclasto de K-feldspato circundado por matriz de quartzo recristalizado por bulging e fita monominerálica de quartzo. 
compostas por grãos inequigranulares de contatos irregulares, formados em reposta à recristalização por migração de limites de grão. Os relictos de quartzo, geralmente bordejados pelos agregados, apresentam extinção ondulante. O quartzo comumente forma agregados policristalinos alongados e lenticulares, descontínuos, com relictos mostrando extinção ondulante e ocorrem, ainda, como fitas monocristalinas (Figura 14F).

A biotita é o mineral que melhor marca a foliação nos $\mathrm{GAD}$, formando lamelas orientadas, de aproximadamente $0,1 \mathrm{~mm}$, ou compondo inclusões euédricas e parcialmente alteradas para clorita nos feldspatos. Tem predominantemente coloração castanho avermelhada para $\mathrm{n}_{\mathrm{g}}$.

Nos diques sinplutônicos, a composição é diorítica, M' 20, contendo anfibólio precoce e biotita tardia como minerais máficos. A foliação é marcada pela orientação das lamelas de biotita, principalmente, e indicadores cinemáticos apontam para o movimento sinistral, evidenciando a mesma dinâmica de fluxo de entrada dos GAD. Zonas de mistura são evidenciadas pelo contato gradacional entre dique e GAD, em que a quantidade de minerais máficos reduz gradativamente à medida que aumenta a quantidade de minerais quartzo-feldspáticos. A composição dos veios que injetam esses diques é a mesma dos GAD; no entanto, suas estruturas não mostram a mesma deformação destes. Tal fato poderia ser atribuído ao strain softening dado pelo líquido parcialmente cristalizado do dique intrudido, que teria absorvido parte da deformação local. Nesses veios, ao contrário dos $\mathrm{GAD}$, os feldspatos estão bem preservados e somente o quartzo é afetado pela recristalização dinâmica por migração de limite de grão.

\section{CONSIDERAÇÕES FINAIS}

A ZCQSE constitui uma das ramificações de espessura quilométrica pertencentes ao CCSb. Tem direção $060-065^{\circ}$ e seu movimento é transcorrente anti-horário, com componente oblíqua subordinada. Essa zona de cisalhamento estabeleceu-se sobre um embasamento paleoproterozoico representado pelo CAR e concentrou a deformação sobre os granitoides gerados sincronicamente ao seu movimento. Assim, também agiu como protagonista, condicionando a geração e ascensão dos magmas nela alojados.

Granitoides sincrônicos à atividade tectônica representam importantes marcadores da evolução cinemática de uma zona de cisalhamento. Por sua vez, os GAD, cuja assinatura estrutural é marcada por estruturas tardi-magmáticas que avançam progressivamente para estruturas subsolidus e, subsequentemente, para estruturas de mais baixa temperatura, têm em suas estruturas tardias parte do registro da evolução da ZCQSE. O caráter sintectônico dessas rochas, dado pela cristalização concomitante a um episódio de deformação sob condições de temperatura decrescente, é evidenciado pela ocorrência de estruturas magmáticas sobrepostas, de modo concordante, por estruturas típicas de deformação no estado sólido de altas a baixas temperaturas. A ausência de truncamento das estruturas primárias pelas estruturas deformacionais é um forte indício da relação de contemporaneidade entre as atividades magmática e transcorrente.

O presente estudo evidencia a heterogeneidade estrutural dos GAD, caracterizada principalmente pela distribuição da deformação na intrusão, que culmina no desenvolvimento alternado de zonas de baixa e alta deformação, indicando a operação de diferentes mecanismos e intensidades deformacionais durante o posicionamento dessas rochas.

Uma vez que a temperatura é um dos principais agentes indutores dos processos de deformação intracristalina, especialmente em quartzo e feldspatos, esses minerais têm sido amplamente utilizados como ferramenta para delinear as condições termais em zonas de cisalhamento dúctil. Conforme Stipp et al. (2002b), nos cristais de quartzo os mecanismos de retrabalhamento e as diferentes microestruturas de recristalização variam em função das condições de deformação. Por meio de estudos experimentais em agregados de quartzo, Hirth e Tullis (1992) demonstram que a migração de limite de grãos se dá a altas temperaturas, enquanto a recristalização por bulging ocorre a baixas temperaturas. Isso também é sugerido por Rosenberg e Stünitz (2003), que inferem temperaturas acima de $400^{\circ} \mathrm{C}$ para a migração de limite de grão e o intervalo de $200-300^{\circ} \mathrm{C}$ para a recristalização por bulging, enquanto para Stipp et al. (2002a) esse intervalo é compreendido entre $280-400^{\circ} \mathrm{C}$. Para Tullis (1983), a temperatura mínima requerida para a deformação plástica desse mineral é de $280^{\circ} \mathrm{C}$. Assim, a ocorrência de cristais de quartzo recristalizados por migração de limite de grão (Regime 3, de Hirth e Tullis, 1992) e por bulging (Regime 1, de Hirth e Tullis, 1992), aliada à formação de agregados policristalinos e cristais com extinção ondulante, sugere que diferentes mecanismos de recristalização dinâmica e plasticidade intracristalina atuaram durante os processos de deformação dos GAD. A ocorrência de duas gerações de subgrãos ortogonais - resultantes da ativação dos sistemas basal-a e prismático-c para acomodar as deslocações - constituindo o padrão tabuleiro de xadrez (chessboard pattern - Kruhl, 1996; Mainprice et al., 1986) em cristais de quartzo nessas rochas marca condições de alta temperatura, da ordem de aproximadamente $650^{\circ} \mathrm{C}$, em estudos de Stipp et al. (2002a).

O grau de recristalização dinâmica nos cristais de K-feldspato e plagioclásio dos GAD é variável, sendo a recristalização desenvolvida especialmente nas bordas dos cristais, preferencialmente por rotação de subgrão, eventualmente se estendendo para as regiões mais internas do cristal. Para Yund e Tullis (1991), o mecanismo 
de recristalização dominante no plagioclásio resulta do lento volume de difusão em feldspatos, similar ao processo de bulging que ocorre para o quartzo, ao passo que Kruse et al. (2001) apontam a progressiva rotação de subgrão como processo de recristalização dominante nesses cristais. Para Rosenberg e Stünitz (2003), o desenvolvimento de recristalização dinâmica no plagioclásio se dá, provavelmente, em função de altas temperaturas que permitem a mobilidade dos limites de grão e a formação de subgrãos devido à presença de deslocações. Ainda, conforme Rosenberg e Stünitz (2003), a recristalização por bulging nos feldspatos é desencadeada em baixas temperaturas, em torno de $400-500^{\circ} \mathrm{C}$, enquanto os mecanismos de recristalização por rotação de subgrão e migração de limite de grão ocorrem a temperaturas de mais de $550^{\circ} \mathrm{C}$. Fitz Gerald e Stünitz (1993) assinalam que a recristalização por rotação de subgrão é subordinada à migração de limites de grãos em feldspatos naturalmente deformados. Como consequência, sob regimes de baixa temperatura da fácies xisto verde superior até regimes de mais alta temperatura da fácies granulito, as microestruturas nos feldspatos em rochas naturalmente deformadas exibem mecanismos de recristalização similares àqueles desenvolvidos nos cristais de quartzo em temperaturas da ordem da fácies xisto verde inferior a xisto verde.

Subgrãos grandes desenvolvidos em cristais de plagioclásio e K-feldspato, restritos às bordas dos cristais nas rochas estudadas, ainda que com pouca expressão, são compatíveis com temperaturas elevadas de deformação, necessárias para a ativação de vários sistemas de deslizamento, o que, para esses minerais, requer temperaturas acima de $550^{\circ} \mathrm{C}$ (Fitz Gerald e Stunitz, 1993). Localmente, é possível observar a progressão de grão-subgrão-grão recristalizado, em um processo de recuperação e acomodação da deformação.

Intercrescimentos mirmequíticos formados nas bordas de alguns cristais de feldspato, tanto nas zonas de baixa quanto nas de alta deformação, apontam que o processo de mirmequitização foi gerado durante deformação de estado sólido, como sugerido por Vernon (1991). A deformação que gera essa feição também pode reduzir o tamanho de grão dos feldspatos, o que, conforme Vernon et al. (1983), comumente ocorre em condições compatíveis com as de alto grau. Para De Toni et al. (2016), a correlação entre os processos de deformação e a formação de mirmequitas tem relação íntima com a atuação efetiva de fluidos nos processos de dissolution-replacement creep e reaction-softening, responsáveis por acomodar e concentrar a deformação das rochas por meio de reações de dissolução, substituição e precipitação de minerais e difusão de massa assistida por fluidos.

Microfraturas extensionais nos cristais de feldspatos, seladas por grãos recristalizados de quartzo, cuja morfologia é compatível com a dos grãos recristalizados da matriz, com a qual mostram continuidade óptica, são descritas por Büttner (1999) como características de condições magmáticas e apontam para a presença de líquido durante a deformação plástica desses cristais. Esse comportamento rúptil dos feldspatos, possivelmente, representa o estágio final da deformação de alta temperatura, antecedendo a fase de mais baixa temperatura.

Feições de deformação de alta temperatura, como cristais de quartzo com subgrãos em padrão tabuleiro de xadrez, bem como de K-feldspato e plagioclásio com subgrãos grandes, indicam que o sistema sofreu deformação em temperaturas da ordem de $650^{\circ} \mathrm{C}$ (Kruhl, 1996; Passchier e Trouw, 2005), compatíveis com as da fácies anfibolito superior e com a temperatura solidus de composições graníticas. Essas estruturas de alta temperatura, por sua vez, refletem as temperaturas magmáticas da intrusão tectônica, em vez das condições de P-T do ambiente. Dada a preservação de algumas estruturas e texturas ígneas, juntamente com a geração das feições de deformação de estado sólido de alta temperatura, é possível concluir que a evolução estrutural e microestrutural dos GAD se caracteriza pela presença de deformação desde o estágio magmático, configurando uma sequência contínua entre os processos magmáticos e os de deformação de estado sólido.

O caráter de baixa temperatura é comprovado por feições como recristalização com geração de grãos ultrafinos bem desenvolvida em quartzo, comumente por bulging, fraturas dos cristais de feldspato seladas por material fino da matriz intensamente recristalizada, neoformação de grãos finos ao redor dos cristais de feldspatos de maior tamanho e desenvolvimento de pertitas em chamas nos Kfs, indicando deformação em temperaturas da ordem de $300 \mathrm{a} 450^{\circ} \mathrm{C}$, bem abaixo da solidus, compatíveis com as da fácies xisto verde. Essa deformação de baixa temperatura sobreposta às feições de mais alta temperatura, nas mesmas estruturas, é indicativa da evolução do evento de alta temperatura, comprovando que a progressão do rebaixamento da temperatura da zona de cisalhamento é controlada pelo resfriamento do magma. Dessa forma, as estruturas de estado sólido que se estabelecem quando intrusão e encaixante entram em equilíbrio térmico, o que envolve processos de recristalização dinâmica em quartzo e feldspatos compatíveis com temperaturas da fácies xisto verde médio a superior, podem refletir as condições de P-T ambientais.

As idades U-Pb em zircão obtidas para o GCS e os GSA, aliadas às relações de campo e estruturais, permitem estabelecer o posicionamento dos GAD no intervalo entre essas rochas, sugerindo um intervalo de tempo reduzido entre seus alojamentos. Somando-se a isso, as condições de $\mathrm{P}$ calculadas a partir do geobarômetro $\mathrm{Al}^{\mathrm{t}}-\mathrm{Hb}$ no GCS são estimadas em 4,3 a 5,3 kbars (Knijnik et al., 2013). Assim, supondo-se um gradiente normal de pressão, 
essas condições equivalem a cerca de $15 \mathrm{~km}$ de profundidade na crosta, compatível com temperaturas da ordem de $450^{\circ}$ nas encaixantes. Por sua vez, a temperatura mínima dada pelas microestruturas dos GAD permite estimar que o posicionamento dessas rochas tenha se dado em condições semelhantes às do GCS, quando este já se encontrava cristalizado.

\section{REFERÊNCIAS}

Almeida, F. F. M., Hasui, Y., Brito Neves, B. B., Fuck, R. A. (1981). Brazilian structural provinces: an introduction. Earth-Science Reviews, 17(1-2), 1-29. https://doi. org/10.1016/0012-8252(81)90003-9

Bitencourt, M. F. (1996). Granitóides sintectônicos da região de Porto Belo, SC: Uma abordagem petrológica e estrutural do magmatismo em zonas de cisalhamento. Tese (Doutorado). Porto Alegre: Instituto de Geociências - Universidade Federal do Rio Grande do Sul.

Bitencourt, M. F., Nardi, L. V. S. (2000). Tectonic setting and sources of magmatism related to the Southern Brazilian Shear Belt. Revista Brasileira de Geociências, 30(1), 184-187. https://doi.org/10.25249/0375-7536.2000301186189

Bitencourt, M. F., Nardi, L. V. S. (2004). The role of xenoliths and flow segregation in the genesis and evolution of the Paleoproterozoic Itapema Granite, a crustally derived magma of shoshonitic affinity from southern Brazil. Lithos, 73(1-2), 1-19. https://doi.org/10.1016/j.lithos.2003.08.004

Büttner, S. (1999). The geometric evolution of structures in granite during continuous deformation from magmatic to solid-state conditions: an example from the central European Variscan Belt. American Mineralogist, 84(11-12), 1781-1792. https://doi.org/10.2138/am-1999-11-1207

Centeno, A. (2012). Os granitóides sintectônicos pós-colisionais Sanga do Areal, intrusivos no Complexo Arroio dos Ratos, na região de Quitéria, RS. Dissertação (Mestrado). Porto Alegre: IGEO/UFRGS.

De Toni, G., Bitencourt, M. F., Nardi, L. V. S. (2016). Strain partitioning into dry and wet zones and the formation of Ca-rich myrmekite in syntectonic syenites: a case for meltassisted dissolution-replacement creep under granulite facies conditions. Journal of Structural Geology, 91, 88-101. https://doi.org/10.1016/j.jsg.2016.08.002

Fernandes, L. A. D., Tommasi, A., Porcher, C. C., Vieira Jr., N., Marques-Toigo, M., Guerra-Sommer, M., Piccoli, A. E.
(1988). Mapa geológico de parte das folhas de Quitéria e Várzea do Capivarita - RS, Quitéria, folha SH 22-Y-B-I-4, estado do Rio Grande do Sul, Várzea do Capivarita, folha SH 22-Y-B-I-3, escala 1:50.000. Porto Alegre: UFRGS. Série Mapas. $1 \mathrm{v}$.

Fitz Gerald, J. D., Stünitz, H. (1993). Deformation of granitoids at low metamorphic grade I: Reactions and grain size reduction. Tectonophysics, 221(3-4), 269-297. https:// doi.org/10.1016/0040-1951(93)90163-E

Fontana, E., Nardi, L. V., Bitencourt, M. F. (2009) Afinidade toleítica médio a alto-K das rochas dioríticas e granodioríticas sintranscorrente do Cinturão de Cisalhamento Sul-brasileiro na região de Quitéria, Rio Grande do Sul. XII Congresso Brasileiro de Geoquímica. Ouro Preto: SBGq.

Fontana, E., Nardi, L. V. S., Bitencourt, M. F., Knijnik, D. B. (2012). Caracterização geoquímica e petrogenética dos Granitoides Arroio Divisa, região de Quitéria, Rio Grande do Sul. Geologia USP. Série Científica, 12(3), 33-56. https:// doi.org/10.5327/Z1519-874X2012000300003

Fragoso Cesar, A. R. S. (1980). O Cráton Rio de La Plata e o Cinturão Dom Feliciano no Escudo Uruguaio-Sulriograndense. XXXI Congresso Brasileiro de Geologia, 5 , 2979-2892. Balneário Camboriú: SBG.

Frantz, J. C., McNaughton, N. J., Hartmann, L. A., Botelho, N. F., Caravaca, G. (2003). SHRIMP U-Pb zircon ages of granitoids from southernmost Brazil: constraints on the temporal evolution of the Dorsal de Canguçu Transcurrent Shear zone and the eastern Dom Feliciano Belt. IV South American Symposium on Isotope Geology. Short papers, 174-177. Salvador.

Gregory, T. R., Bitencourt, M. F., Nardi, L. V. S. (2011). Caracterização estrutural e petrológica de metatonalitos e metadioritos do Complexo Arroio dos Ratos na sua seção-tipo, região de Quitéria, RS. Pesquisas em Geociências, 38(1), 85-108. https://doi.org/10.22456/1807-9806.23837

Gregory, T. R., Bitencourt, M. F., Nardi, L. V. S., Florisbal, L. M., Chemale Jr., F. (2015). Geochronological data from TTG-type rock associations of the Arroio dos Ratos Complex and implications for crustal evolution of southernmost Brazil in Paleoproterozoic times. Journal of South American Earth Sciences, 57, 49-60. https://doi.org/10.1016/j. jsames.2014.11.009

Hirth, G., Tullis, J. (1992). Dislocation creep regimes in quartz aggregates. Journal of Structural Geology, 14(2), 145-159. https://doi.org/10.1016/0191-8141(92)90053-Y 
Knijnik, D. B. (2018). Geocronologia U-Pb e geoquímica isotópica $\mathrm{Sr}$-Nd dos granitóides sintectônicos às zonas de cisalhamento transcorrentes Quitéria Serra do Erval e Dorsal de Canguçu, Rio Grande do Sul, Brasil. Tese (Doutorado). Porto Alegre: Instituto de Geociências - Universidade Federal do Rio Grande do Sul.

Knijnik, D. B., Bitencourt, M. F., Gregory, T. R. (2013). A Zona de Cisalhamento Quitéria-Serra do Erval e o magmatismo sintectônico precoce do Cinturão de Cisalhamento Sul-brasileiro. XI Simpósio Nacional de Estudos Tectônicos. Ouro Preto.

Knijnik, D. B., Bitencourt, M. F., Nardi, L. V. S., Pinto, V. M., Fontana, E. (2012). Caracterização Geoquímica do Granodiorito Cruzeiro do Sul: magmatismo shoshonítico pós-colisional neoproterozoico em zona de transcorrência, região de Quitéria, RS. Geologia USP. Série Científica, 12(1), 17-38. https://doi.org/10.5327/Z1519-874X2012000100003

Knijnik, D. B., Bitencourt, M. F., Nardi, L. V. S., Pinto, V. M., Santos, J. O. S., McNaughton, N. J. (2010). U-Pb (SHIRIMP) Zircon geochronology of the Cruzeiro do Sul Granodiorite post-collisional shoshonitic magmatism from Southern Brazil. VII - SSAGI South American Symposium on isotope geology. Brasília.

Koester, E., Chemale Jr., F., Porcher, C. C., Bertotti, A. L., Fernandes, L. A. D. (2008). U-Pb ages of granitoids from Eastern Sul-riograndense Shield. VI South American Symposium on Isotope Geology, p. 95. San Carlos de Bariloche.

Kruhl, J. H. (1996). Prism- and basal-plane parallel subgrain boundaries in quartz: a microstructural geothermobarometer. Journal of Metamorphic Geology, 14(5), 581-589. https:// doi.org/10.1046/j.1525-1314.1996.00413.x

Kruse, R., Stünitz, H., Kunze, K. (2001). Dynamic recrystallization processes in plagioclase porphyroclasts. Journal of Structural Geology, 23(11), 1781-1802. https:// doi.org/10.1016/S0191-8141(01)00030-X

Mainprice, D., Bouchez, J. L., Blumenfeld, P., Tubià, J. M. (1986). Dominant $c$ slip in naturally deformed quartz: implications for dramatic plastic softening at high temperature. Geology, 14(10), 819-822. https://doi. org/10.1130/0091-7613(1986)14<819:DCSIND $>2.0 . C O ; 2$

McCaffrey, K. J. W., Miller, C. F., Karlstrom, K. E., Simpson, C. (1999). Syn-magmatic deformation patterns in the Old Woman Mountains, SE California. Journal of Structural Geology, 21(3), 335-349. https://doi.org/10.1016/ S0191-8141(98)00107-2
Mulchrone, K. F., Grogan, S., De, P. (2005). The relationship between magmatic tiling, fluid flow and crystal fraction. Journal of Structural Geology, 27(2), 179-197. https://doi. org/10.1016/j.jsg.2004.10.007

Nardi, L. V. S., Bitencourt, M. F. A. S. (2007). Magmatismo granítico e evolução crustal no sul do Brasil. In: R. Ianuzzi, J. C. Frantz (Eds.), 50 anos de Geologia, Instituto de Geociências. Contribuições (1, 125-139). Porto Alegre.

Passchier, C. W., Trouw, R. A. (2005). Microtectonics. Berlim: Springer. 372 p. https://doi.org/10.1007/3-540-29359-0

Paterson, S. R., Vernon, R. H., Tobisch, O. T. (1989). A review of criteria for the identification of magmatic and tectonic foliations in granitoids. Journal of Structural Geology, 11(3), 349-363. https://doi.org/10.1016/0191-8141(89)90074-6

Picada, R. S. (1971). Ensaio sobre a tectônica do Escudo Sul-rio-grandense. Caracterização dos sistemas de Falhas. XXV Congresso Brasileiro de Geologia, 1, 167-191. São Paulo: SBG.

Rosenberg, C. L., Stünitz, H. (2003). Deformation and recrystallization of plagioclase along temperature gradient: an example from the Bergell tonalite. Journal of Structural Geology, 25(3), 389-408. https://doi.org/10.1016/ S0191-8141(02)00036-6

Stipp, M., Stünitz, H., Heilbronner, R., Schmid, S. M. (2002a). Dynamic recrystallization of quartz: correlation between natural and experimental conditions. In: S. De Meer, M. R. Drury, J. H. P. de Bresser, G. M. Pennock (Eds.), Deformation Mechanisms, Rheology and Tectonics: Current Status and Future Perspectives. Geological Society of London, Special Publications, 200(1), 171-189. Londres: Geological Society of London. https://doi.org/10.1144/GSL. SP.2001.200.01.11

Stipp, M., Stünitz, H., Heilbronner, R., Schmid, S. M. (2002b). The eastern Tonale fault zone: a "natural laboratory" for crystal plastic deformation of quartz over a temperature range from 250 to $700^{\circ}$ C. Journal of Structural Geology, 24(12), 1861-1884. https://doi.org/10.1016/S0191-8141(02)00035-4

Tullis, J. (1983). Deformation of feldspars. In: P. H. Ribbc (Ed.), Feldspar Mineralogy, 2, 297-323. Mineralogical Society of America Reviews in Mineralogy.

Tullis, J., Yund, R. A. (1991). Diffusion creep in feldspar aggregates: experimental evidence. Journal of Structural Geology, 13(9), 987-1000. https://doi. org/10.1016/0191-8141(91)90051-J 
Vernon, R. H. (1991). Questions about myrmekite in deformed rocks. Journal of Structural Geology, 13(9), 979-985. https:// doi.org/10.1016/0191-8141(91)90050-S

Vernon, R. H. (2000). Review of Microstructural Evidence of Magmatic and Solid-State Flow. Electronic Geosciences, 5(2), 1-23 https://doi.org/10.1007/s10069-000-0002-3

Vernon, R. H., Williams, V. A., D’arcy, W. F. (1983). Grainsize reduction and foliation development in a deformed granitoid batholith. Tectonophysics, 92(1-3), 123-145. https:// doi.org/10.1016/0040-1951(83)90087-2

Walker,G.P.L.(1969). The breaking ofmagma. Geological Magazine, 106(2), 166-173. https://doi.org/10.1017/S0016756800051979

Yund, R. A., Tullis, J. (1991). Compositional changes of minerals associated with dynamic recrystallization. Contributions to Mineralogy and Petrology, 108(3), 346-355. https://doi.org/10.1007/BF00285942 